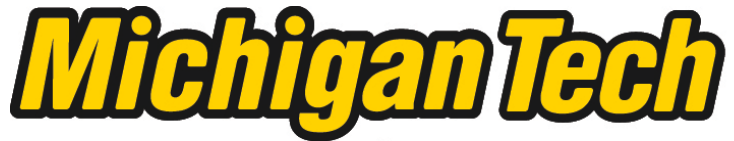 \\ Michigan Technological University Create the Future Digital Commons @ Michigan Tech
}

\section{Economic viability of shale gas production in the Marcellus Shale; indicated by production rates, costs and current natural gas prices}

Ryan J. Duman

Michigan Technological University

Follow this and additional works at: https://digitalcommons.mtu.edu/etds

Part of the Agricultural and Resource Economics Commons

Copyright 2012 Ryan J. Duman

\section{Recommended Citation}

Duman, Ryan J., "Economic viability of shale gas production in the Marcellus Shale; indicated by production rates, costs and current natural gas prices", Master's Thesis, Michigan Technological University, 2012.

https://doi.org/10.37099/mtu.dc.etds/446

Follow this and additional works at: https://digitalcommons.mtu.edu/etds

Part of the Agricultural and Resource Economics Commons 


\title{
ECONOMIC VIABILITY OF SHALE GAS PRODUCTION IN THE MARCELLUS SHALE; INDICATED BY PRODUCTION RATES, COSTS AND CURRENT NATURAL GAS PRICES
}

\author{
By \\ Ryan J. Duman \\ A THESIS \\ Submitted in partial fulfillment of the requirements for the degree of \\ MASTER OF SCIENCE \\ (Applied Natural Resource Economics) \\ MICHIGAN TECHNOLOGICAL UNIVERSITY \\ 2012 \\ (C)2012 Ryan Duman
}


This thesis, "Economic Viability of Shale Gas Production in the Marcellus Shale; Indicated by Production Rates, Costs and Current Natural Gas Prices ," is hereby approved in partial fulfillment of the requirements for the Degree of MASTER OF SCIENCE IN APPLIED NATURAL RESOURCE ECONOMICS.

School of Business and Economics

Signatures:

Thesis Advisor

Dr. Mark Roberts

Committee Member

Dr. Gary Campbell

Committee Member

Dr. Roger Turpening

Dean

Dr. Darrell Radson

Date 


\section{Table of Contents}

List of Figures ……

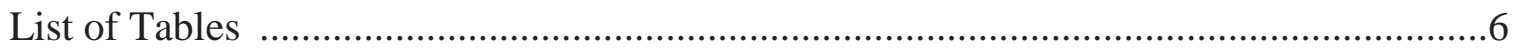

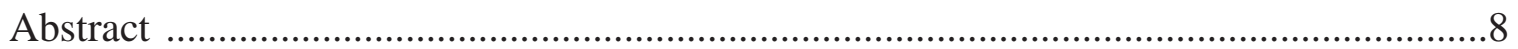

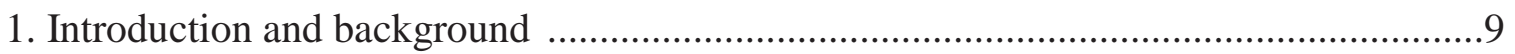

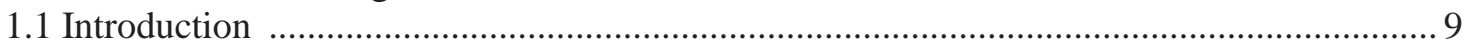

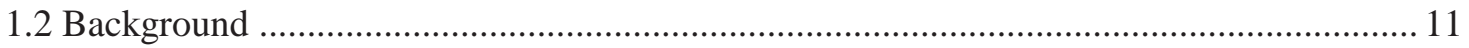

2. Economic concerns associated with shale gas production............................................15

2.1 Limited shale gas production and economic data available …………………………....... 15

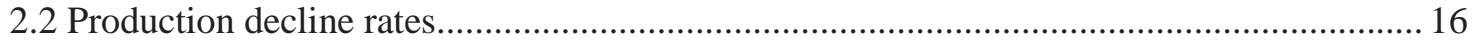

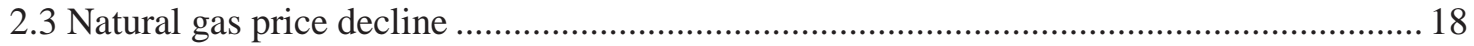

2.4 Oversupply issues and slow growth in domestic natural gas demand ................................ 19

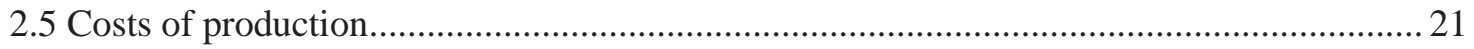

2.6 Current status of Marcellus Shale operations ................................................................. 23

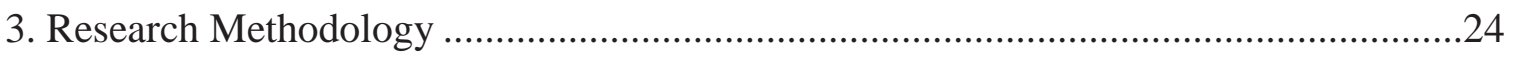

3.1 Overview of the analysis ......................................................................................... 24

3.2 Lease acquisition and royalty costs .........................................................................2.

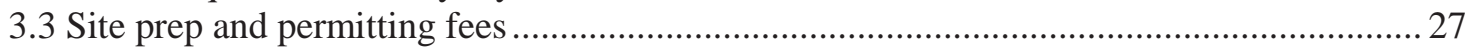

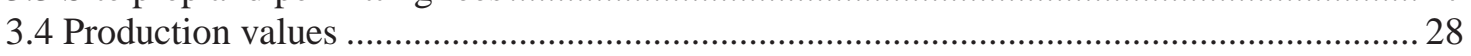

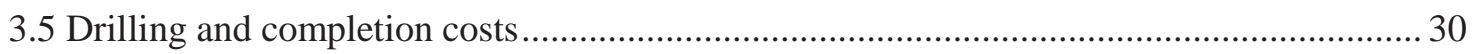

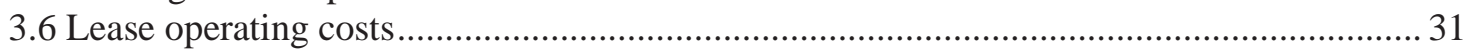

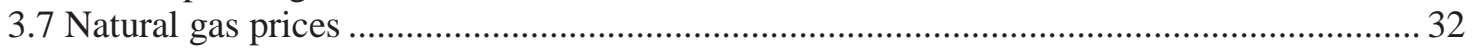

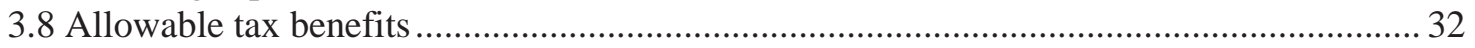

3.9 State and federal corporate income taxes .......................................................................... 36

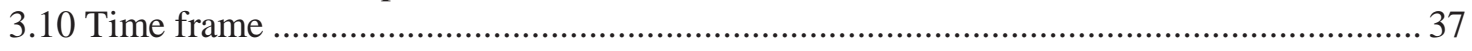

3.11 Resulting calculations ............................................................................................... 40

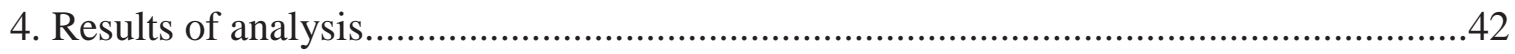

4.1 Simulated well production values................................................................................. 42

4.2 Ten-year cash flow statement ....................................................................................... 49

4.3 Twenty-year cash flow statement assuming no workovers or re-stimulation ...................... 53

4.4 Twenty-year cash flow statement with workovers and re-stimulation ..............................59

4.5 Cash flow statement with a shale gas well drilled in year zero and a second in year ten.... 65

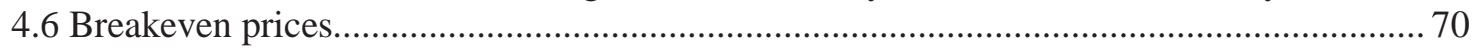

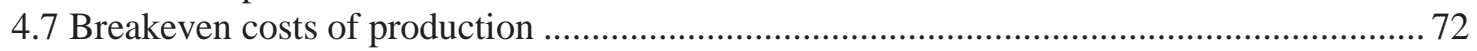

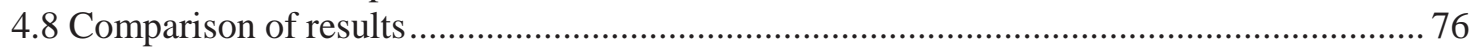

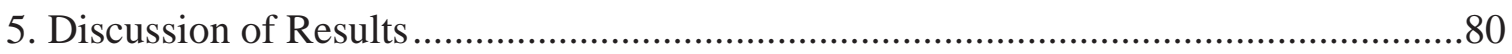

5.1 Effects of production declines on the economic performance of the shale gas well ...........81 81

5.2 Impact of increased production costs on overall profitability …………………………...... 82 
5.3 Oversupply and slow growth in demand could cause trouble in the future. 85

5.4 The importance of the price of natural gas on overall profitability .....................................90

5.5 Methods to increase economic favorability of shale gas operations ................................ 92

5.6 Importance of the allowable tax deductions used in the analysis ...................................... 94

5.7 Tolerance for future volatility while maintaining profitability .........................................96

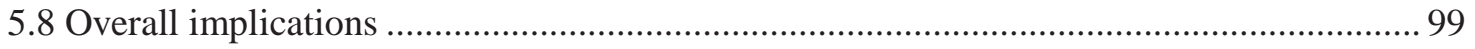

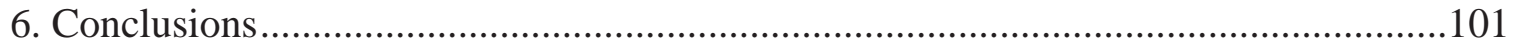

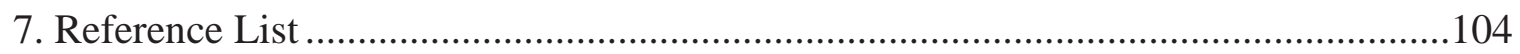




\section{List of Figures}

Figure 4.1 Production decline curve for a shale gas well with ten years of natural gas production.

Figure 4.2 Production decline curve for a shale gas well with twenty years of natural gas

production.

Figure 4.3 Production decline curve for a shale gas well with twenty years of production including workovers and re-stimulation efforts

Figure 4.4 Percent of total natural gas that can be expected to be recovered in a given time period

Figure 4.5 Cash flow statement for a shale gas well with ten years of production .50

Figure 4.6 Cash flow statement for a shale gas well with twenty years of production .....54

Figure 4.7 Cash flow statement for a shale gas well with twenty years of production including workovers and re-stimulation efforts .60

Figure 4.8 Cash flow statement for twenty years with one well being drilled in year one and a second well drilled in year ten

Figure 4.9 Breakeven costs of production for a shale gas well with ten years of production.

Figure 4.10 Breakeven costs of production for a shale gas well with twenty years of production

Figure 4.11 Breakeven costs of production for a shale gas well with twenty years of production including workovers and re-stimulation efforts

Figure 4.12 Breakeven costs of production for twenty years of natural gas production with a shale gas well being drilled in year 0 and year 10 


\section{List of Tables}

Table 3.1 Depreciation rates according to the 7-year modified accelerated cost recovery system

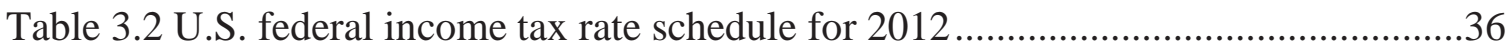

Table 4.1 Input values used to create the production decline curves.....

Table 4.2 Input values used for cost related variables in the cash flow statements

Table 4.3 Results from the cash flow statement with ten years of production

Table 4.4 Results from the cash flow statement with twenty years of production .58

Table 4.5 Results from the cash flow statement with twenty years of production including workover and re-stimulation efforts

Table 4.6 Results from the cash flow statement with a shale gas well being drilled in year zero and ten 70

Table 4.7 Breakeven price results for all scenarios .71

Table 4.8 Breakeven costs of production based on varying amounts of natural gas production

Table 4.9 Breakeven cost of production based on five billion cubic feet of natural gas production

Table 4.10 Comparison of the results found from each of the cash flow statements ........77

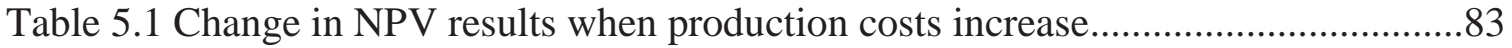

Table 5.2 Results when the price of natural gas varies............................................. 86 
Table 5.3 Comparison of results based on twenty years of production with no workovers versus two shale gas wells being drilled .87

Table 5.4 Results when the price of natural gas is kept constant in the cash flow statements

Table 5.5 Change in NPV results if natural gas prices decline and production costs increase 


\begin{abstract}
The U.S. natural gas industry has changed because of the recent ability to produce natural gas from unconventional shale deposits. One of the largest and most important deposits is the Marcellus Shale. Hydraulic fracturing and horizontal drilling have allowed for the technical feasibility of production, but concerns exist regarding the economics of shale gas production. These concerns are related to limited production and economic data for shale gas wells, declines in the rates of production, falling natural gas prices, oversupply issues coupled with slow growth in U.S. natural gas demand, and rising production costs. An attempt to determine profitability was done through the economic analysis of an average shale gas well using data that is representative of natural gas production from 2009 to 2011 in the Marcellus Shale. Despite the adverse conditions facing the shale gas industry it is concluded from the results of this analysis that a shale gas well in the Marcellus Shale is profitable based on NPV, IRR and breakeven price calculations.
\end{abstract}




\section{Introduction \& Background}

\subsection{Introduction}

The U.S. supply of natural gas has drastically changed as a result of unconventional natural gas recovered from shale deposits. Analysts estimate the U.S. may now have access to a domestic supply of natural gas able to meet several decades' worth of demand (Energy Information Administration 2012b). While it remains to be seen how much gas will actually be produced, there has been enough activity associated with shale gas deposits to have caused a boom in drilling and production in the past decade. This has changed our previous natural gas supply situation from that of relative scarcity to one of overabundance. Natural gas already accounts for a significant proportion of energy used in the U.S. and securing additional reserves can be beneficial economically, politically and even environmentally speaking. Natural gas is approximately 30 percent cleaner burning compared to oil and 45 percent cleaner burning than coal (Energy Information Administration 2009). As a result, many people believe that increasing our use of natural gas can serve as an intermediate energy solution helping bridge the gap between "dirty" fossil fuels, such as coal and oil, to more renewable energy sources, such as solar and wind. The extraction and utilization of a domestic energy source of this magnitude can have huge economic implications for numerous stakeholders such as local economies benefiting from job creation and increased income through royalty payments. Furthermore, the development of a relatively clean, affordable, domestic energy resource that can put Americans back to work and decrease 
our imports of foreign natural gas makes shale gas a politically popular trend for both Democrats and Republicans. While there are several shale gas deposits currently being developed in the U.S. one of the most promising and talked about is the Marcellus Shale. It is predominantly located in Pennsylvania and Upstate New York and has gained significant attention due to its proximity to major population areas, the amount of potentially recoverable gas and the size of the deposit.

Shale gas plays such as the Marcellus Shale sound enticing initially with all of the potential benefits but recent market factors related to the natural gas industry have brought about concerns regarding the economics of shale gas production (Jacoby, O'Sullivan and Paltsev 2012). Circumstances working against the profitability of shale gas in the Marcellus Shale include falling natural gas prices, severe overproduction issues, a decade of rising costs and significant production declines in the shale gas wells (Energy Information Administration 2012b). Through an economic analysis of this situation, profitability of a typical shale gas well found in the Marcellus Shale will be examined by taking a closer look at production and cost variables. It will then be possible to determine whether or not producers are able to profitability extract natural gas from the Marcellus Shale given the current adverse market conditions. Profitability will be gauged by calculating useful metrics such as the net present value and internal rate of return of the simulated well along with the breakeven price of gas that is necessary for producers in the Marcellus Shale to make a profit.

Issues such as the potential environmental problems associated with shale gas production and the impact those allegations could have on shale gas economics are beyond the scope of this analysis but will be addressed in chapter 5. In addition, this 
analysis focuses on the factors that are present as of 2011 and those that have a high probability of occurring in the future. While there are numerous potential benefits to developing the Marcellus Shale it first must be determined whether or not natural gas producers can do so in a profitable manner.

\subsection{Background}

Natural gas deposits can be classified as conventional or unconventional based on the geological attributes of the deposit. Conventional natural gas is produced from welldefined reservoirs with good permeability and is in contrast to unconventional natural gas, which is characterized by low permeability, and is usually deposited over geographically large areas than conventional deposits (Jacoby, O'Sullivan and Paltsev 2012). Unconventional natural gas deposits in shale formations have been known about for over a hundred years but it has only been in the last twenty years or so that producers have been able to access and extract the gas in both an economically and technically feasible fashion. The utilization of horizontal drilling and hydraulic fracturing are responsible for allowing producers to technologically extract natural gas from shale deposits (Jacoby, O'Sullivan and Paltsev 2012). Horizontal drilling allows for greater access to the gas-rich rock by curving the well when the drill reaches the shale deposit. The well can then continue to be drilled for several thousand feet within the shale, allowing for greater well exposure to gas-dense rock. Horizontal drilling does not alone allow for adequate gas production due to the low permeability of shale deposits. To increase permeability, well stimulation is required and the use of hydraulic fracturing 
(referred to as "fracking") has been found to be effective in shale deposits to adeauatley increase permeability. Fracking works by pumping a slurry mixture into the well under extremely high pressure until the formation fractures. The slurry mixture is composed predominantly of water and chemicals such as biocides, friction-reducers and corrosion inhibitors along with sand or ceramic beads to allow the fractures to remain open. This process is typically done a number of times before the well is able to sufficiently produce gas (Arthur, Bohm and Layne 2009). The cost however to produce natural gas from shale deposits as compared to conventional natural gas production is more expensive because of the need to utilize horizontal drilling and hydraulic fracturing. Despite the increased costs associated with shale gas production there has been a recent frenzy in domestic gas production in the past decade and great success for companies and investors who have joined in on the shale gas boom (O'Neil 2010).

The utilization of horizontal drilling and hydraulic fracturing has lead to the development of several shale gas deposits throughout the U.S. Some of these deposits include the Barnett Shale in Texas, Marcellus Shale in Pennsylvania and New York, Fayetteville Shale in Arkansas, Woodford Shale in Oklahoma, and the Haynesville Shale in Louisiana and Arkansas (Energy Information Administration 2011b). It is the Marcellus Shale that has garnered the most attention though. This shale deposit has become so prevalent because of its proximity to major population areas in the northeast, the size of the deposit, the potential economic benefits and alleged environmental issues. The core producing area of the Marcellus play, which is the area capable of producing the greatest quantity of gas, is approximately 16-32 million acres, extending from northeast West Virginia through Pennsylvania and into New York (Baylor 2010). This makes the 
core area of the Marcellus Shale significantly larger than other shale deposits. However, many companies are focusing their attention primarily on producing gas within Pennsylvania due to state incentives to drill there and a significant portion of the state being within the core area. A current estimate indicates that the Marcellus Shale could produce more than 12 billion cubic feet $(\mathrm{Bcf})$ of natural gas per day by the end of 2012 and by 2015 production could increase to 17.5 Bcf per day (O'Neil 2010). These numbers correlate to the Marcellus Shale being able to produce approximately one-sixth to one-quarter of the annual U.S. domestic natural gas demand each year (Naturalgas.org 2011). The total estimated amount of recoverable gas in the Marcellus Shale is projected to be approximately 141 trillion cubic feet of natural gas. This amount of natural gas equates to approximately 6 years of total U.S. demand for natural gas produced from the Marcellus Shale alone (Energy Information Administration 2012b).

In addition to size and gas estimates, the Marcellus Shale is unlike other shale deposits located in the southern or western parts of the U.S. because of its proximity to several large population centers in the Northeast. One implication of this is lower transportation costs for the gas, which typically must be transported via pipeline from states such as Texas, Oklahoma or Wyoming. This is important because the Northeast contains a significant proportion of the U.S. population and consequently is an area where a considerable amount of energy demand occurs. The phenomenon in the Marcellus region is also responsible for putting thousands of people to work, in jobs both directly and indirectly related to the natural gas industry. Direct employment is in reference to those individuals working in the exploration and production of the natural gas whereas indirect employment refers to the jobs created in response to the increase in 
population of natural gas workers coming into Pennsylvania. The natural gas boom in the Marcellus Shale has also resulted in landowners, who sit atop of natural gas deposits, being compensated through bonus checks and royalties; occasionally amounting to hundreds of thousands of dollars (Natural Gas Forum for Landowners 2011). The positive economic benefits of the shale gas boom have resulted in the addition of muchneeded money into the local economies of Pennsylvania (O'Neil 2010). The continuation of these economic benefits from natural gas production in the Marcellus Shale relies entirely on companies being able to produce the gas in a profitable manner. Circumstances have begun to change, however, within the natural gas industry that could significantly change the economics of this phenomenon. 


\section{Economic Concerns Associated with Shale Gas Production}

While technology has made it feasible to now extract natural gas from the Marcellus Shale and there are indications for why it would be advantageous to do so, the economic viability of this gas play is not yet clear. First, it costs more to produce natural gas from shale deposits than it does from conventional deposits because of the need for horizontal drilling and hydraulic fracturing. In addition, there are other problems with shale gas production based on recent market changes in the natural gas industry that raise concerns about the economic viability of this phenomenon. The circumstances working against favorable shale gas economics include falling natural gas prices, overproduction issues, a decade of rising production costs and significant production decline rates experienced in shale gas wells. All of these conditions are related to one another and affect the overall profitability of shale gas activities in the Marcellus Shale. As more information is gathered and market conditions continue to deteriorate there are more indications that it is becoming increasingly difficult for producers of shale gas to achieve reliable profits.

\subsection{Limited Shale Gas Production and Economic Data Available}

The first issue, which raises concerns about shale gas economics, is the limited data currently available for the long-term production characteristics and economic performance of shale gas wells in the Marcellus Shale. The shortage of data is a result of the infancy of the shale gas industry. It has only been within the last decade that 
companies have had success producing commercial quantities of natural gas in the Marcellus Shale as a result of the utilization of horizontal drilling and hydraulic fracturing. Shale gas plays that have been producing for longer periods of time include the Barnett Shale in Texas and the Fayetteville Shale in Arkansas, with each of these plays producing gas since the 1980's. The Barnett Shale and Fayetteville Shale were two of the first plays to utilize horizontal drilling and hydraulic fracturing and have generated the greatest amounts of data available for the production and economic performance of shale gas wells (Baylor 2010). The information from these two shale gas plays has been used to compare new well production data in recently developed shale deposits such as the Marcellus shale. This comparison of data is thought to be acceptable because the geologic qualities of all three shale deposits are similar. While similarity is important and can lead to useful extrapolation of data, there is no guarantee that the wells drilled in the Marcellus Shale will behave in the same fashion (Baylor 2010). Overall, the lack of data on the long-term performance of shale gas wells in the Marcellus Shale results in a strong reliance on forecasts and analysis to predict what may happen.

\subsection{Production Decline Rates}

While a lot of data may not exist relating to the long-term performance of shale gas wells, it is known with certainty that all wells will experience significant declines in productivity over time. Shale gas wells experience production declines due to the low permeability characteristics of shale deposits and the low concentration of gas, spread over large areas. Wells typically found in the Marcellus Shale will experience a 
production decline rate of approximately $65-85$ percent within the first twelve months with subsequent declines in production throughout the remaining life of the well (Considine 2010). Depending on how the productivity of the well is modeled, and what the initial production values are, the EUR (expected ultimate recovery) for the well can vary considerably. The EUR calculations are critically important as they are used to forecast the expected revenue, depletion calculations and overall profitability of the well. With highly variable EURs, the economics of shale gas wells can quickly change from positive to negative. Many shale gas wells found in the Marcellus Shale have EUR values of approximately four to five billion cubic feet of natural gas (Baylor 2010).

The decrease in production each year correlates to decreased annual revenue from the well as there is less gas being produced which can be sold. Intensifying this dilemma is the fact that producers often enter into contracts for which they are required to produce a certain quantity of gas for a stated amount of time. While these contracts can be financially beneficial to the producers, they require them to ensure an adequate and reliable supply of natural gas. As wells decline in productivity, producers have to make certain that new highly productive wells are available to come online to make up the slack. The other option besides drilling new wells is to increase productivity of an existing well by subjecting them to additional well stimulation. While more hydraulic fracturing over time helps to increase productivity, it is also the most capital-intensive aspect of shale gas well development. Hydraulic fracturing typically represents approximately 40 to 60 percent of total well completion costs, which can result in costs greater than two million dollars (Hefly et al., 2011). Several re-stimulation requirements can quickly alter the profitability of a well and the increases in productivity are not 
permanent. Producers must make certain that the re-stimulation efforts are able to increase production by a great enough amount to recoup the high costs of additional stages of hydraulic fracturing. If producers are unable keep production levels high while maintaining a certain level of profitability they must continually drill more wells in order to account for decreasing well production.

\subsection{Natural Gas Price Decline}

In addition to limited data availability and production decline issues, shale gas economics have also been negatively affected by the falling price of natural gas. In the past three years the price of gas has fallen more than 75 percent from approximately ten dollars per thousand cubic foot (mcf) in 2008 to a price of around three to four dollars per mcf in 2011 (Energy Information Administration 2012a). Two of the most important reasons for this price collapse were the financial crisis causing a quick, severe drop in price and a current oversupply of natural gas further decreasing and holding prices under four dollars per mcf. The financial crisis in 2008 caused price decreases in almost all commodities and while some have since recovered, natural gas has not seen any considerable upward price momentum (Krauss 2008) (Energy Information Administration 2012a). Furthermore, the current market conditions for natural gas have resulted in forecasts by the Energy Information Administration that do not expect average annual wellhead prices of natural gas to increase much past $\$ 5.00$ until at least 2025

(Energy Information Administration 2010). When prices for gas were around ten dollars per mcf there was a higher tolerance for higher production costs of shale gas and the 
ability to offer high royalty and bonus amounts because producers were able to make several dollars profit on every mcf of natural gas they could sell. The low natural gas prices however may make even the most profitable projects seem perhaps only marginally profitable and cause companies to begin to reevaluate production activities in the Marcellus Shale (Fahey 2012).

\subsection{Oversupply issues and slow growth in domestic natural gas demand}

While the financial crisis in 2008 caused the initial drop in natural gas prices they have been further decreased and held low as a result of stagnant demand and a current state of oversupply. Neither supply nor demand factors are working in favor of shale gas economics, which are two forces that could help increase the price. Total U.S. demand for natural gas is only expected to increase by approximately one percent per year from 2009 through 2035 (Energy Information Administration 2011). This forecast includes the fact that much of the new electricity capacity additions in the next two decades would be fueled by natural gas (Energy Information Administration 2011). One of the primary reasons there will not be significant increases in the U.S. demand for natural gas is a result of the high efficiency gains in natural gas power plants, commercial buildings and residential appliances (Energy Information Administration 2011). Additionally, the U.S. is a developed economy and there is no indication that we would need substantially more amounts of energy from natural gas in the near future. This is opposed to a country such as China, which is a rapidly developing economy and requires an increasing amount of energy each year to support the growing infrastructure, consumer and commercial 
demand. Consequently, as a result of demand only increasing by a few percent each year for the foreseeable future, it cannot be expected that increases in natural gas demand will help raise prices by any sizeable amount.

The boom in shale gas production has lead to many companies actively pursuing natural gas projects throughout the United States and especially in the Marcellus Shale. Producers have now become a victim of their own success and have created a supply glut. The supply of natural gas in the U.S. is 21 percent higher than the five-year average as of early 2012 (Holl 2012). There are estimates that in March of 2012 the supply of natural gas will be at its highest levels since 1983 (Flynn 2012). Overall, the supply of gas has been increasing at rates much too fast for demand to keep up and the U.S. has found itself with a surplus of natural gas. This overabundance of natural gas is acting to prevent any increase in price and is actually forcing prices lower as production continues to increase and the quantity of gas remains significantly greater than the domestic demand for gas (Energy Information Administration 2012b).

The oversupply of natural gas coupled with low prices should signal producers to slow production in order to help increase prices. Many companies however are doing the opposite and increasing production to help compensate for low gas prices in order to maintain revenues and attempt to increase profits (Smith 2009). Additionally, producers rarely shut-in wells when prices are low, also working to keep the gas supply high. Producers do not shut-in their gas wells because there are contract issues prohibiting any production restriction, reservoir characteristics inhibiting the ability to stop production and financial reasons such as the net present value of the revenues received from the natural gas produced, which often all motivate a company to produce as much gas as they 
can now instead of shutting-in the well and producing later (Naturalgas.org 2011) (Parent 2010).

\subsection{Costs of Production}

The necessity for horizontal drilling and hydraulic fracturing of shale gas wells before they produce sufficient quantities of natural gas increases production costs as compared to conventional natural gas wells. Due to the geological factors of conventional natural gas deposits including high permeability characteristics and welldefined reservoirs, natural gas can be produced in commercial quantities from conventional reservoirs by drilling vertical wells down into the deposit with no need for stimulation efforts (Naturalgas.org 2010). Performing several stages of fracking however, to ready a shale gas well for production can cost a producer upwards of two to three million dollars per well (Hefley, et al. 2011). The greater costs of production for shale gas were more tolerable when gas prices were increasing and at the high levels of ten dollars per mcf. In addition, higher production costs associated with shale gas deposits such as the Marcellus Shale can be justified by the potential opportunity to produce larger quantities of natural gas when compared to other domestic conventional gas deposits (Considine 2010).

The rise in natural gas prices that helped incentivize the boom in shale gas production in the Marcellus Shale helped result in a decade worth of increasing production costs. Equipment and operating costs related to shale gas production were increasing since the early 2000's at rates much faster than the price of natural gas 
(Energy Information Administration 2010). The frenzy for companies to acquire lease rights and begin to produce gas in the Marcellus Shale caused a surge in land and equipment demand and a resulting shortage of drilling-related items. Almost all costs of shale gas development including drill rigs, personnel, well casing, drilling supplies and fracking equipment saw increases in price. From 2002 to 2008 average lease operating costs and equipment costs increased 60 percent and 65 percent respectively (Energy Information Administration 2010). The rising costs of production have been working in the opposite direction of what needs to happen given the low price of natural gas. As the price of natural gas falls, companies are not able to accept high costs and still make profits.

It is possible that a peak in production costs has been reached as the trend of increasing costs has recently begun to reverse slightly. Costs had been increasing since the early 2000's until 2009 when operating and equipment costs both started to decline by several percent (Energy Information Administration 2010). This was a result of several factors including greater supplies of drilling equipment becoming available, a learning curve affect decreasing costs and low prices slowing the boom in the Marcellus as companies reevaluate their drilling activities (Schaefer 2009) (Energy Information Administration 2010). There is still growing demand for drilling equipment and any recovery in natural gas prices could cause production costs to rapidly increase again in the future. 


\subsection{Current Status of Marcellus Shale Operations}

The above conditions have resulted in concerns in regards to the overall economics of shale gas activities in the Marcellus Shale. Investors, landowners, and other involved stakeholders worry that companies are no longer able to profitability produce natural gas in the Marcellus Shale. While circumstances facing the shale gas industry are bad, companies are able to tolerate some flexibility in high costs and low prices. This is indicated by companies still actively pursuing lease rights and increasing drilling efforts in the face of factors such as high production costs, low natural gas prices and a current overabundance of domestic gas (Range Resources Corp. 2011) (Chesapeake Energy Corporation 2011). The question then becomes how much more can these companies tolerate and, given the current circumstances, how profitable are shale gas wells in the Marcellus Shale? 


\section{Research Methodology}

\subsection{Overview of the analysis}

As a result of the recent boom in production of natural gas from the Marcellus Shale and the concerns related to shale gas economics, an analysis was completed to gain better insight into the profitability of a gas well typically found in the Marcellus Shale. The results of this analysis were used to determine if the current adverse circumstances facing the shale gas industry inhibit profitability. In order to model the performance of a typical Marcellus well, various production and cost components associated with shale gas wells were combined to create several cash flow statements. The production and cost variables in the analysis used input values representative of those currently found in the Marcellus Shale. The cash flow statements allowed for the ability to calculate various useful metrics of profitability including the internal rate of return (IRR) of the simulated well, the net present value (NPV) of the cash flows and the necessary breakeven price companies require in order to obtain a minimum return on investment. Profitability was gauged based on whether the values were positive or negative for the resulting NPV calculations, if the IRR values were greater than the minimum acceptable rate of return of 10 percent and if the current price for natural gas was greater than or less than the resulting breakeven price. It was necessary to include numerous components within the analysis and various assumptions had to be made to allow for the simulation of a natural gas well found in the Marcellus Shale. The subsequent sections of this chapter will explain the components of the analysis and the assumptions that were made. 


\subsection{Lease acquisition and royalty costs}

This model included lease acquisition and royalty costs to allow for a full-cycle cost analysis. Many economic analyses justify not including cost items such as lease acquisition costs as they can be deemed sunk costs (Dizard 2010) (MIT Energy Initiative 2010). The amount of money spent on lease acquisitions and royalties to land owners represents a significant amount of required capital and not including these variables in the analysis could easily give a false sense of overall profitability of a Marcellus Shale natural gas well.

To legally drill a natural gas well on private land, producers must offer landowner's incentives including the payments of a signing bonus and royalties. The signing bonus for the land rights is in the form of a predetermined dollar amount per acre and the royalty payments represent additional income for landowners based on a percentage of revenues from the natural gas produced, before any costs or taxes are factored in (Hefley, et al. 2011). In order to successfully drill for shale gas, producers typically require a minimum unit of land consisting of 640-acres (one square mile) (Green 2010). Because most people do not own 640 contiguous acres of land, the 640acre unit can be comprised of several individual smaller lease agreements, to meet the total minimum unit size of land (Green 2010). For the purpose of this analysis it was assumed that all landowners, who might be included in the 640 -acre lease unit, were offered the same lease conditions and thus the lease calculations can be thought of in terms of a complete singular unit. Lease bonus payments in the Marcellus Shale can 
range from several hundred dollars per acre to over $\$ 10,000$ per acre with the current average being approximately $\$ 3,450$ per acre (Green 2010) (Natural Gas Forum for Landowners 2011). The analysis assumed that the landowners would be offered the average lease bonus rate and a total lease bonus expense of $\$ 2,208,000$ for the 640 -acre lease unit was used.

In addition to the bonus payment, landowners are also entitled to a percentage of the natural gas produced from a completed well, before any costs or taxes are factored in. The amount of gas to be paid as royalties to the landowner utilizes the average annual wellhead price of gas in the given year in which the royalties are to be paid. The royalty rates in the Marcellus Shale currently range from a minimum of 12.5 percent to 18 percent with the average rate being offered in Pennsylvania being roughly seventeen percent (Green 2010) (Natural Gas Forum for Landowners 2011). Similar to the lease bonus payment rate, the analysis assumed the average royalty rate of seventeen percent was offered to the landowners.

After the terms of the lease agreements are settled upon and the landowners sign the contract, a company gains the right to drill and extract natural gas from that land for a set time period, typically with the ability to automatically renew the lease if desired. Leases signed in the Marcellus Shale are commonly written for five year terms and can be automatically renewed for an additional five years, if the property is productive or if the producer wishes to keep the lease for future drilling opportunities (Green 2010). The analysis assumed that the lease would be renewed for each five-year period, throughout the life of the well at which time a new bonus payment would be paid to the landowners. 
The same per-acre lease amount of $\$ 3,450$ and royalty amount of 17 percent remained constant with each lease renewal.

\subsection{Site prep and permitting fees}

In addition to the lease acquisition and royalty costs, there are other expenses associated with the preparation of the drilling site and the permitting necessary to drill for natural gas. To drill a natural gas well in the Marcellus Shale in Pennsylvania, a permit must be obtained from the Department of Environmental Protection and operators are also required to post a bond (Department of Environmental Protection (DEP) 2009). The purpose of these two actions are to help the state monitor drilling activities and decrease the likelihood of any environmental disturbances, as a result of natural gas production (Department of Environmental Protection (DEP) 2009). There is an initial application fee to obtain the permit, which is dependent on the total wellbore length of the natural gas well. For this analysis a total wellbore length of 10,000 feet was assumed, which resulted in an application fee of \$2,600 (Department of Environmental Protection (DEP) 2009). As well as submitting the application fee for the Marcellus Shale permit the drilling company must also post a bond. The bond is required to help ensure the operator of the well will address water supply issues, perform drilling operations satisfactorily, plug the well after abandonment and reclaim the site (Department of Environmental Protection (DEP) 2011). The bond amount for a single natural gas well is currently $\$ 2,500$ (Department of Environmental Protection (DEP) 2011). 
After the permits and bond have been acquired there are additional steps that must be taken and costs involved with readying the site for drilling. These steps include constructing a road on the land to transport supplies and people, stripping and leveling the drill site, constructing a pond and laying a liner to hold the fluids required for hydraulic fracturing and resulting wastewater, laying rock for the construction of the drilling pad and seeding and matting the surrounding area to help with erosion control (Hefley, et al. 2011). The approximate costs associated with prepping a site for drilling amount to roughly $\$ 400,000$ (Hefley, et al. 2011). When the costs of permits, the bond and site prep are factored together they represented a onetime total expense of approximately $\$ 405,100$. There are instances when producers are able to drill numerous wells from a single drilling pad which would consequently decrease the prep costs for the well but for the simplicity of determining the basic economic outcome of a typical shale gas well in the Marcellus Shale the analysis assumed only one natural gas well would be drilled.

\subsection{Production values}

Determining the amount of natural gas that could potentially be produced by the simulated well was one of the most critical components of the analysis. Actual monthly production values from producers within the Marcellus Shale were difficult to acquire, as they are considered proprietary information. Data was available however regarding the initial rates of production, estimated ultimate recovery (EUR) approximations of the wells, annual decline values and projected type curves of natural gas wells recently 
drilled in the Marcellus Shale. The available production related information allowed for the production values of the simulated well analysis to be calculated by using of a hyperbolic decline equation. This equation calculates the oil and gas decline curves. Companies traditionally utilize this equation to show the average well performance in an area (Society of Petroleum Evaluation Engineers (SPEE) 2002). The hyperbolic decline equation that was used is in the form of:

$$
\left.\mathrm{q}_{\mathrm{t}}=\mathrm{q}_{\mathrm{i}}^{*}\left(1+\mathrm{b} * \mathrm{D}_{\mathrm{i}} * \mathrm{t}\right)\right)^{(-1 / \mathrm{b})}
$$

where,

$\mathrm{q}_{\mathrm{t}}=$ production rate at time $\mathrm{t}$ (volume/time)

$\mathrm{q}_{\mathrm{i}}=$ production rate at time 0 (volume/time)

$\mathrm{D}_{\mathrm{i}}=$ initial nominal decline rate at $\mathrm{t}=0(1 /$ time $)$

$\mathrm{b}=$ hyperbolic exponent

$\mathrm{t}=$ time (months)

The data required to produce the curve was chosen to be representative of what the most active producers in the Marcellus Shale have been experiencing. The producers, which were used to estimate these values include Chesapeake Energy (Chesapeake Energy Corporation 2011), Range Resources (Range Resources Corp. 2011), Cabot Oil and Gas (Cabot Oil and Gas Corp 2011) and EQT Corporation (EQT Corp. 2011). The production decline equation allowed for an accurate approximation of what the monthly production values for a typical Marcellus Shale gas well should be. For the purpose of 
the cash flow statements constructed in the analysis, the monthly production values were combined to show the annual amounts of natural gas produced by the well. The production decline curve also allowed for the ability to calculate the EUR of the simulated shale gas well, by taking the sum of the cumulative natural gas produced for a given period of time. It is important to also note that the well constructed in the analysis assumed that production would be completely limited to dry-gas, which is characteristic of many wells drilled in the Marcellus Shale (Cox 2012). Dry-gas production refers to the production of primarily methane (the primary constituent of natural gas). This is in contrast to a well that produces wet-gas, which means the well produces methane along with other natural gas liquids including butane, ethane and propane (Naturalgas.org 2010).

\subsection{Drilling and completion costs}

The drilling and completion costs (D\&C costs) associated with natural gas wells are those expenses incurred related to the drilling of the shale gas well and the steps taken to ready the well for production. The drilling component of $\mathrm{D} \& \mathrm{C}$ costs is the vertical and horizontal drilling stages of the well and represents approximately 40 percent of the total D\&C costs (Hefley, et al. 2011). The second aspect of D\&C costs are those expenses of the completion activities, which consist primarily of the stimulation efforts (hydraulic fracturing), along with other additional expenses such as the casing and cementing the well (Naturalgas.org 2010). Completion costs often comprise the majority of the total D\&C costs typically ranging from 50 to 60 percent of the total drilling and completion 
expense (Hefley, et al. 2011). The simulated Marcellus Shale well assumed total drilling and completion costs of $\$ 4.5$ million and was based off of average $D \& C$ costs, incurred in the Marcellus Shale, for Chesapeake Energy (Chesapeake Energy Corporation 2011), Range Resources (Range Resources Corp. 2011), Cabot Oil and Gas (Cabot Oil and Gas Corp 2011), and EQT Corporation (EQT Corp. 2011).

\subsection{Lease operating costs}

After the well has been drilled and completed to allow for production, there are additional costs associated with the day-to-day production of natural gas and getting the gas to the gathering system. These costs are referred to as the lease operating costs (LOC's) and consist of the direct lifting costs including labor, repairs and maintenance of the well, materials and supplies, in addition to administration costs (Range Resources Corp. 2011). Lease operating costs represent the primary reoccurring annual cash costs incurred throughout the economic life of the well. The annual lease operating costs were calculated based on a per unit cost and the value of $\$ 0.70$ per mcf of natural gas was chosen based on average LOC's listed in articles and SEC 10-k filings for corporations producing natural gas in the Marcellus Shale (EQT Corp. 2011) (Cabot Oil and Gas Corp 2011) (Chesapeake Energy Corporation 2011) (Range Resources Corp. 2011). The lease operating costs were assumed to remain constant at $\$ 0.70$ per mcf throughout the life of the well. 


\subsection{Natural gas prices}

The price of natural gas used in the Marcellus Shale well analysis was based on calculations and forecasts for the average annual wellhead price of natural gas from U.S. Energy Information Administration (E.I.A.). The wellhead price of natural gas represents the price per unit of natural gas a producer charges before costs associated with gathering, transportation and refinement are included (Federal Energy Regulatory Commission 2010). This price of natural gas was chosen to represent what natural gas prices producers would likely factor into their forecasts for the projected financial performance of their shale gas wells. A starting price of natural gas of $\$ 4.04$ per mcf was used in the analysis and is representative of the annual average wellhead price of gas for 2011 (Energy Information Administration 2011). An average annual increase in wellhead gas prices of 2.1 percent per year was assumed in the analysis and was chosen based on E.I.A. natural gas price forecasts for 2009 to 2035 (Energy Information Administration 2011).

\subsection{Allowable tax benefits}

Several allowable tax deductions for the oil and gas industry were factored into the cash flow statements before determining the amount of taxes to be paid for the simulated Marcellus Shale well. All of the tax deductions used in the analysis are considered allowable tax benefits for all oil and gas operations and are not exclusive to 
shale gas activities (Western Capital Inc. 2007) (Internal Revenue Service 2011). The allowable tax deductions utilized in the analysis included:

\subsubsection{Intangible Drilling Cost (IDC) Tax Deduction}

Drilling and completion costs associated with the natural gas well can be divided into the two categories of intangible drilling costs and tangible drilling costs. The intangible costs of drilling include such items as labor, chemicals used in the completion process, drilling fluid and additional items associated with the drilling and completion activities that offer no salvage value (PetroChase 2009). These expenses can be counted as a deduction in the year in which the intangible drilling costs were incurred (Internal Revenue Service 2011). For the purpose of this analysis the intangible drilling costs were assumed to be $75 \%$ of the total drilling and completion costs, which falls under the allowable deduction range of $65-80 \%$ of the total cost of a well (Western Capital Inc. 2007). Given the assumption that total D\&C costs for the simulated Marcellus Shale well was $\$ 4.5$ million the IDC cost value was assumed to be $\$ 3,375,000$.

\subsubsection{Tangible Drilling Cost Tax Deduction}

As opposed to IDC expenses, the tangible drilling costs represent those costs relating to the drilling and completion costs that do offer salvage value. These expenses include the equipment used in the drilling and completion of the well and are allowed to be depreciated over a seven year period utilizing the Modified Accelerated Cost 
Recovery System or MACRS (PetroChase 2009). The 7-year depreciation schedule for property is shown in Table 3.1 (Internal Revenue Service 2010).

Table 3.1

Depreciation rates according to the 7 -year modified accelerated cost recovery system.

\begin{tabular}{|l|l|}
\hline \multicolumn{2}{|c|}{$\begin{array}{c}\text { 7-year MACRS } \\
\text { Depreciation Schedule }\end{array}$} \\
\hline Year & Percentage \\
\hline 1 & $14.29 \%$ \\
\hline 2 & $24.49 \%$ \\
\hline 3 & $17.49 \%$ \\
\hline 4 & $12.49 \%$ \\
\hline 5 & $8.93 \%$ \\
\hline 6 & $8.93 \%$ \\
\hline 7 & $8.93 \%$ \\
\hline 8 & $4.46 \%$ \\
\hline
\end{tabular}

Tangible drilling costs generally comprise $25 \%$ of the total cost of a well or the remaining portion of the total $\mathrm{D} \& \mathrm{C}$ costs that were not able to be counted under IDC costs (Western Capital Inc. 2007). Based on the total D\&C costs of $\$ 4.5$ million for this analysis, the tangible drilling costs were assumed to account for depreciable expense of $\$ 1,125,000$.

\subsubsection{Depletion Allowance}

There are two methods used to calculate depletion for natural gas activities and include cost depletion and statutory depletion. This analysis assumed the simulated Marcellus Shale well was an asset of an integrated energy company and not owned by an 
independent producer and as a result, cost depletion was utilized. Statutory depletion is based on a percentage basis and is allowed only for independent natural gas producers (Internal Revenue Service 2010). The cost based depletion technique calculates how much depletion can be accounted for each year based on a per-unit value of natural gas. All costs incurred related to the leases are included in the depletion calculations and are 100 percent tax deductible through cost depletion (PetroChase 2009). These costs included lease acquisition expenses and lease operating costs in the analysis. Cost depletion was calculated using the following method (Alexander 2005) (Everett and O'Neil 2001):

Cost Depletion $=\begin{gathered}\begin{array}{c}\text { Unrecoverable depletable costs at } \\ \text { the end of the year }\end{array} \\ \begin{array}{c}\text { Estimated remaining units at the } \\ \text { beginning of the year }\end{array}\end{gathered} \quad \begin{gathered}* \text { The number of units } \\ \text { sold during the year }\end{gathered}$

The calculation of the unrecoverable depletable costs included the residual investment, which is the "original leasehold cost, plus lease operating costs, less the value at the end of operations, less the cumulative depletion deducted in previous years" (Alexander 2005). The value of the estimated remaining units was determined based on the initial value calculated for the well's EUR less the cumulative production of natural gas to that point in time (Internal Revenue Service 2010). The number of units sold in a given year was assumed to be 100 percent of the total annual production in that given year. 


\subsection{State and federal corporate income taxes}

Additional expenses, as a result of state and federal taxes, were accounted for after allowable tax deductions were included in the cash flow. A state corporate tax rate of 9.99 percent was utilized in the analysis and is representative of the current flat-rate corporate tax rate in Pennsylvania (Federation of Tax Administrators 2011). The state tax amount was used as an allowable deduction for the federal income taxes. The amount of federal corporate income taxes owed, for the Marcellus Shale well analysis, was determined by use of the federal corporate income tax formula, which is:

Tax $=$ base tax + tax rate $*$ (federal taxable income - lower value of income bracket)

The base tax and tax rate values, which were used, were dependent on the amount of federal taxable income for that year and which income bracket the taxable income fell under and the respective values are shown in Table 3.2 (Internal Revenue Service 2012).

Table 3.2

U.S. federal income tax rate schedule for 2012

\begin{tabular}{|l|l|l|l|}
\hline \multicolumn{5}{|c|}{ Tax Rate Schedule } \\
\hline Lower bracket & Upper bracket & Base tax & Tax rate \\
\hline 0 & 50,000 & 0 & $15 \%$ \\
\hline 50,000 & 75,000 & 7,500 & $25 \%$ \\
\hline 75,000 & 100,000 & 13,750 & $34 \%$ \\
\hline 100,000 & 335,000 & 22,250 & $39 \%$ \\
\hline 335,000 & $10,000,000$ & 113,900 & $34 \%$ \\
\hline $10,000,000$ & $15,000,000$ & $3,400,000$ & $35 \%$ \\
\hline $15,000,000$ & $18,333,333$ & $5,150,000$ & $38 \%$ \\
\hline $18,333,333$ & & & $35 \%$ on all income \\
\hline
\end{tabular}




\subsection{Scenarios analyzed}

Several scenarios were analyzed in order to test for profitability based on different production and cost related assumptions. The four scenarios analyzed included ten years of production, twenty years of production, twenty years of production including workovers and re-stimulation efforts and twenty years worth of production with one well being drilled in year zero and a second well being drilled in year ten with each well producing gas for ten years. Individual cash flow statements were constructed for each of the four scenarios. The different time frames of production and other assumptions used in the scenarios were chosen to help show the effects of production declines and different timeframes of production on overall profitability.

As a result of the production declines experienced by shale gas wells, the amount of natural gas produced by the wells decreases throughout the life of the well and consequently the economic contribution of each additional unit of natural gas can be expected to decrease. Depending on production characteristics, the well may prove to be only marginally profitable after a few years of production (Brooks 2010). To test the effects of production declines on overall profitability, the first scenario assumed the life of the shale gas well to be ten years. This value was chosen in order to test whether profitability could be achieved after ten years of production based on the assumptions and values used in this analysis.

The second scenario allowed for twenty years of natural gas production. The results from this scenario would serve as a useful comparison with the ten-year scenario 
to see what effect an additional ten years of production has on overall profitability. The production input values used for the ten-year production scenario remained the same for the twenty-year scenario. This resulted in the first ten years of production being identical to the first scenario. Years ten through twenty were then a continuation from the production values calculated for the ten-year production scenario but including an additional ten years in the production decline curve. Furthermore, the cost structure used in the ten-year production scenario was also used in the twenty-year production scenario. To account for the additional ten years of production two additional lease renewal periods were included at years ten and fifteen and cost based depletion calculations were continued from years ten through twenty.

The third scenario also had twenty years worth of production but included the addition of workovers and re-stimulation efforts in year ten. The purpose was to increase the production rates of the simulated well in order to examine the effects on overall profitability. Workovers and re-stimulation efforts allow for the ability to increase natural gas production during the production life of the well. Workovers help increase the production of the natural gas well through maintenance and remedial efforts (Schlumberger 2011). Specific activities include cleaning the well or replacing well casings to increase production rates (Oilgasglossary.com 2012). In addition to workover activities, re-stimulation of the well includes additional stages of hydraulic fracturing to increase permeability, which also improves production rates. While workovers and restimulation increase the production of shale gas wells, they represent a significant expense. Producers must determine whether it is more cost-effective to drill a new well and abandon the current well or if the increases in production will be great enough to pay 
for workovers and re-stimulation in addition to increasing overall profitability. For this analysis workover and re-stimulation costs were assumed to be 60 percent of the original drilling and completion costs $(\$ 3,375,000)$. This value was chosen because it represented the completion costs associated with the shale gas well in year 0 , with the main constituent of those costs being hydraulic fracturing and for the re-stimulation and workover efforts, hydraulic fracturing was again a major component of the costs. Restimulation efforts were then assumed to increase the production rate in year ten to 40 percent of the original initial production rate (1,600 mcf per day). The re-stimulation expense was also listed as an intangible drilling cost in year ten which was similar to the original completion costs, which were used as an allowable tax deduction. The same initial production and cost characteristics that were used in the ten year scenario were also used in this scenario with only years ten through twenty being different.

The fourth scenario analyzed included two shale gas wells being drilled within a twenty year time frame. The first well was assumed to be drilled in year zero and a second well was assumed to be drilled in year ten. Both shale gas wells produced natural gas for ten years and had the same initial production and cost characteristics as the other scenarios. This scenario would produce the greatest amount of natural gas and include the greatest amount of costs and would thus serve as useful comparison with the other scenarios to examine how drilling an additional well impacts profitability. 


\subsection{Resulting calculations}

Several calculations were completed based on the cash flow statements in order to determine the profitability for each of the scenarios. Profitability was gauged based on the results calculated for the net present value (NPV), internal rate of return (IRR) and breakeven price of natural gas for each scenario. The first calculation that was completed was the NPV of each cash flow statement. It represents the amount of money in present day terms equivalent to the complete cash flow. This value was found using a discount rate of ten percent, which has been used as a minimum acceptable rate of return (MARR) in the natural gas industry (MIT Energy Initiative 2010). All results that were greater than zero were considered profitable for the net present value calculations. The IRR of the cash flow statements was the second calculation that was performed. The internal rate of return represents the interest rate that yields a net present value for the cash flow equivalent to zero. The IRR result was considered profitable for any value that was above the MARR of 10 percent.

In addition, the breakeven price of natural gas was found for each cash flow statement. The breakeven price of gas represented the price of natural gas required by the producer of the well to achieve a net present value of $\$ 0$ for the well based on a ten percent discount rate. The initial breakeven price of gas that was found was under the same assumption as the original price of natural gas, in that it was subjected to a 2.1 percent annual price increase. This assumption was made so that the breakeven price would represent the initial minimal acceptable price of natural gas producers need to receive in order to achieve a minimum 10 percent return on investment. For the 
breakeven price of gas to be considered profitable it had to be less than the 2011 annual average wellhead price of natural gas of $\$ 4.04$ per mcf.

The before tax breakeven costs for the shale gas well were also calculated and represent the cost to produce natural gas on a per unit basis. To calculate the breakeven costs for the shale gas well, the cumulative costs were divided by the cumulative production of natural gas for each given year. Hypothetically as more gas was produced, the cheaper it should be to produce each additional unit of natural gas. The costs associated with finding the breakeven cost of natural gas included the royalties, lease acquisition costs, drilling and completion costs, and lease operating costs. 


\section{Results of Analysis}

The goal of this analysis was to evaluate the profitability of a typical shale gas well found in the Marcellus Shale. Profitability was based on net present values, internal rates of return and breakeven prices derived from various cash flow statements. As discussed in chapter 2 there are indications for why shale gas economics may not be favorable given the current circumstances facing the shale gas industry. These circumstances include low natural gas prices, high costs of production and severe declines in the rate of natural gas production throughout the life of the shale gas well. Despite those adverse conditions, the analysis found that by using values that are representative of those currently found in the Marcellus Shale, a typical shale gas well is profitable. This result is based on all of the cash flow statements having positive net present values, internal rates of return greater than the minimum acceptable rate of return of 10 percent and breakeven costs less than the average annual wellhead price of natural gas in 2011. The complete cash flow statements, graphs and tables with the data of the analysis are included in the subsequent sections of this chapter to show the results of the analysis. The cash flow statements were broken into various parts based on years of production, in order to make them presentable in this document.

\subsection{Simulated well production values}

Before the results could be calculated or cash flow statements constructed, it was necessary to create several production decline curves for the analysis. The purpose of 
this is to generate the production values for the cash flow statements in addition to being able to graphically see what the expected production performance of a shale gas well would be under different assumptions. Based on the different assumptions regarding time and production characteristics, the values from the production decline curves served as the primary source of variation between the cash flow statements. The three production decline curves included in this section are representative of those used in the ten-year cash flow statement, twenty-year cash flow statement that assumed no workover or re-stimulation efforts, and the twenty-year cash flow statement that included workovers and re-stimulation efforts. Each of the production decline curves that were created used the same initial input values for each of the production variables. Table 4.1 summarizes the initial input values used:

Table 4.1

Input values used to create the production decline curves.

\begin{tabular}{|l|l|}
\hline \multicolumn{2}{|c|}{ Production input variables } \\
\hline Initial production rate & 4,000 mcf per day \\
\hline Initial annual decline rate & $70 \%$ \\
\hline b-variable & 0.9 \\
\hline
\end{tabular}

The combination of values in Table 4.1 generated a shale gas well that initially produces natural gas at 4,000 mcf per day with a 70 percent decline in production during the first twelve months. The value of the b-variable is unlike the other variables; it is not dependent on the initial production performance of the shale gas well but rather is an estimated number. The b-variable assumes a value between 0 and 1 and determines the severity of the decline in the curve. The greater the value of $b$ the more aggressively the 
curve slopes downward. The chosen value of 0.9 was selected based on decline curve analyses done by natural gas producers in the Marcellus Shale including Chesapeake Energy (Chesapeake Energy Corporation 2011) and Range Resources (Range Resources Corp. 2011). Leaving the initial input values shown in Table 4.1 the same for the different cash flow statements allowed for better comparison of the results for what would happen to the simulated shale gas well based on different assumptions regarding the production characteristics over different time frames.

The first production decline curve shown in Figure 4.1 was constructed for the cash flow statement that assumed ten-years of natural gas production. This resulted in the simulated shale gas well having an estimated ultimate recovery of $4.14 \mathrm{Bcf}$ of natural gas in ten years. The results from this decline curve provided the basis of production values from which the subsequent twenty-year decline curves would result. Furthermore, the production values derived from this decline curve were duplicated for an additional ten years to produce a twenty-year cash flow statement that represented a new shale gas well being drilled in year ten. This had the effect of showing what would occur if two wells were drilled within a twenty-year time span with each well having ten years worth of production. This resulted in the EUR increasing to approximately $8.28 \mathrm{Bcf}$ of natural gas. 


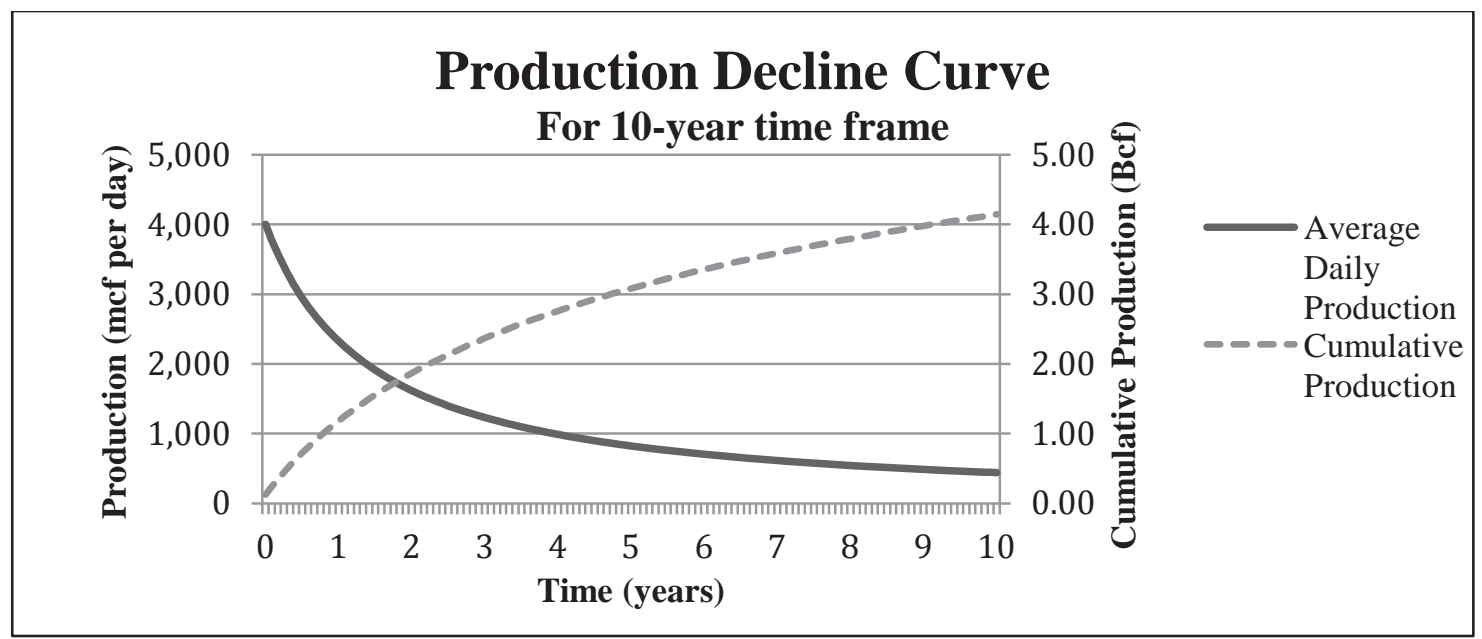

Figure 4.1 - Production decline curve created based on a shale gas well that produces natural gas for ten years. The initial rate of production for the shale gas well is 4,000 mcf of natural gas per day with an annual decline rate of 70 percent. Ten years worth of production equates to a EUR of $4.14 \mathrm{Bcf}$ of natural gas.

The second production decline curve shown in Figure 4.2 was made for twentyyear cash flow statement that assumed no workovers or re-stimulation efforts. This production decline curve was a continuation of the same decline curve as seen in Figure 4.1 but showed the hypothetical production performance of the well for an additional ten years. The estimated ultimate recovery of the shale gas well under the twenty-year assumptions yielded an increase of $1.1 \mathrm{Bcf}$ of natural gas in years ten to twenty, for a cumulative total of $5.24 \mathrm{Bcf}$ of natural gas. 


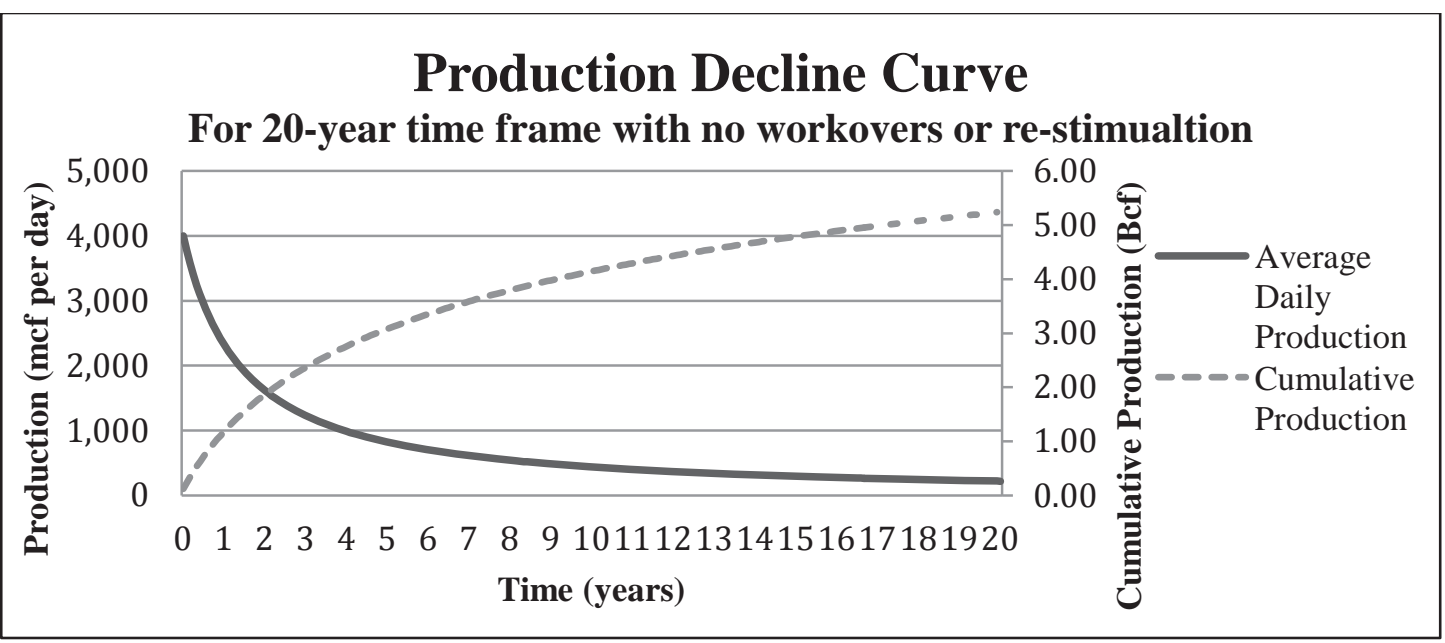

Figure 4.2 - Production decline curve created based on a shale gas well that produces natural gas for twenty years. The initial rate of production for the well is 4,000 mcf of natural gas per day with an annual decline rate of 70 percent. There were no workovers or re-stimulation activities that were assumed to have been performed over the life of the well. Under these assumptions this well would have a EUR of 5.24 Bcf of natural gas.

The third production decline curve shown in Figure 4.3 and shows the performance of the simulated shale gas well under the assumption that well workovers and re-stimulation were completed. The sudden jump in production in year 10 represents the increase in production as a result of the workovers and re-stimulation.

This production increase was assumed to be 40 percent of the original initial production rate. As a result of the greater production from years ten to twenty the estimated ultimate recovery of the well under these assumptions was 5.79 Bcf of natural gas. This represented an overall increase of $0.55 \mathrm{Bcf}$ of natural gas as compared to the twenty-year cash flow where no workovers or re-stimulation efforts were assumed. 


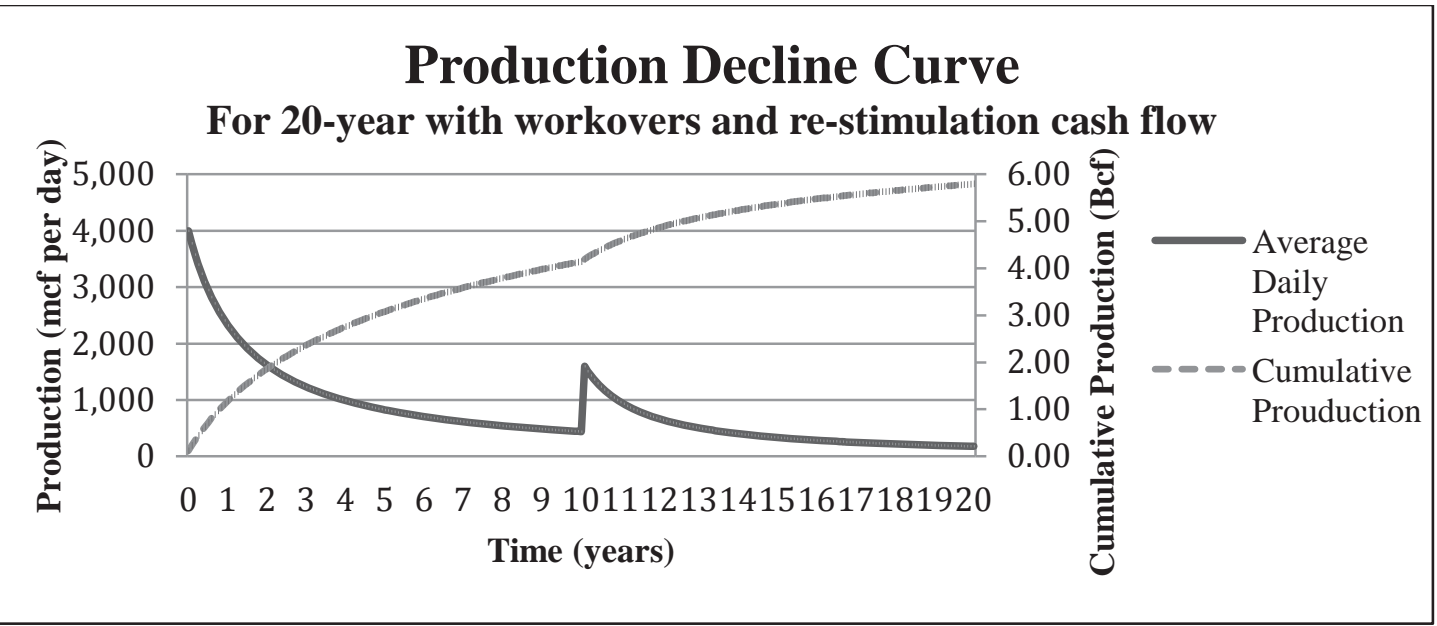

Figure 4.3 - Production decline curve created for a shale gas well that produces natural gas for twenty years with an initial rate of production of 4,000 mcf of natural gas per day and an annual decline rate of 70 percent. In year ten workovers and re-stimulation efforts were assumed to have been completed, which increased the production rate of the shale gas well to 40 percent of the original 4,000 mcf of natural gas per day. These assumptions yield a EUR for the well of 5.79 Bcf of natural gas.

The decline in production over the life of the shale gas well means the majority of producible natural gas will be obtained during the first few years of production. Figure 4.4 illustrates that if the simulated shale gas well has a production life of ten-years then 50 percent of the total expected production will occur after only 29 months of production. 


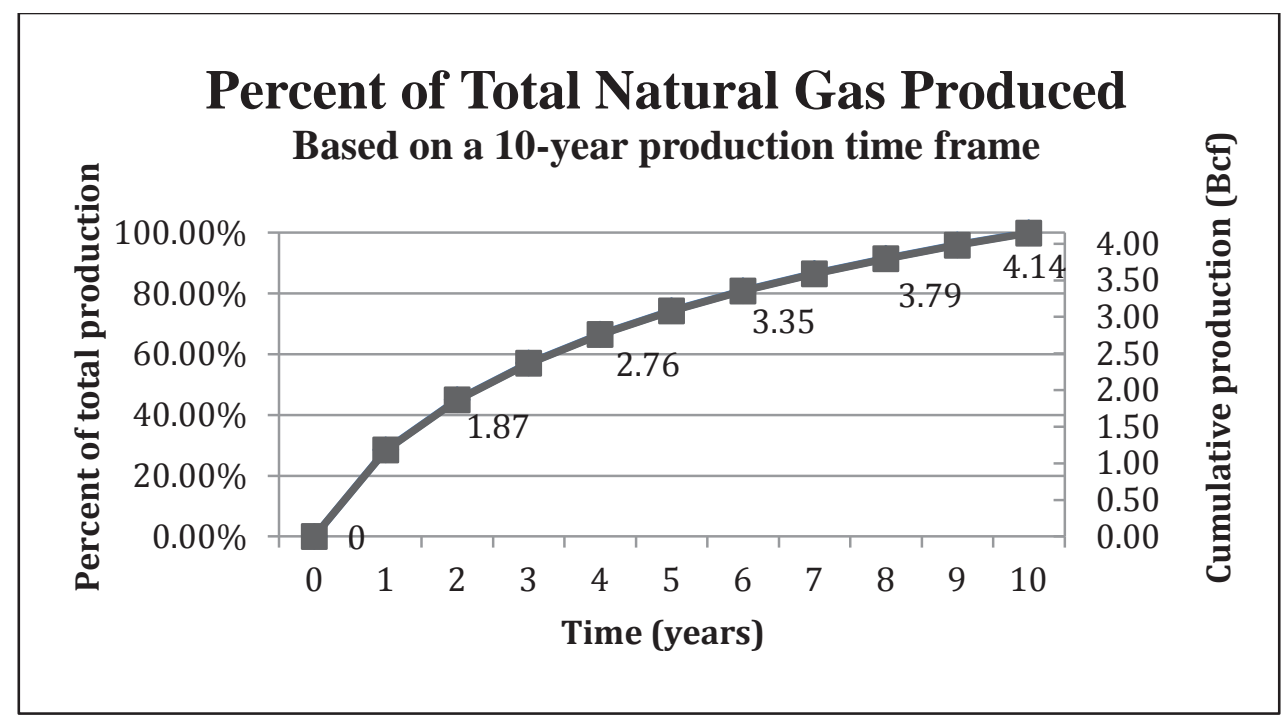

Figure 4.4 - The percent of total natural gas that can be expected to be recovered in a given time period. This is based on a shale gas well that produces natural gas for ten years with an initial rate of production of 4,000 mcf per day and a 70 percent annual decline in production. The EUR of the shale gas well under these assumptions is 4.14 Bcf of natural gas and 50 percent of that EUR is obtained after 29 months of production.

The production decline curves for twenty-years of production assuming no workovers and the twenty-years of production that does assume workovers produce 50 percent of the total expected production in 44 months and 52 months respectively. This means that the shale gas well under these different assumptions produce the first 50 percent of natural gas in approximately the first 5 years of production and the remaining 50 percent of production occurs over a much greater time span of about 15 years. The significance of this is related to the correlation between annual produced gas and annual revenues received from the shale gas well. The amount of revenue a producer can expect to receive in a given year is directly tied with the amount of natural gas that can be produced and sold. As a result of the declines in production experienced by shale gas wells, producers can expect the revenue received from the well to decrease significantly 
after the first few years of production. The implications of this phenomenon will be discussed in detail in chapter 5.

\subsection{Ten-year cash flow statement}

After the production decline curves were created and production values obtained the cash flow statements could then be constructed. The cash flow statements in the analysis utilized production and cost components with initial values representative of those currently found in the Marcellus Shale. Similar to the production decline curves, all cash flow statements assumed the same initial input values for the cost variables.

Table 4.2 summarizes the initial input values used:

Table 4.2

Input values used for cost related variables in the cash flow statements

\begin{tabular}{|l|r|}
\hline \multicolumn{2}{|c|}{ Initial input values for cost variables } \\
\hline Drilling and completion costs & $\$ 4,500,000$ \\
\hline Lease operating costs & $\$ 0.70$ \\
\hline Initial price of natural gas & $\$ 4.04$ per mcf \\
\hline Site prep and permitting fees & $\$ 405,100$ \\
\hline Royalty percentage rate & $17 \%$ \\
\hline $\begin{array}{l}\text { Total lease acquisition costs (based on } \$ 3,450 \\
\text { bonus payment per acre) }\end{array}$ & $\$ 2,208,000$ \\
\hline
\end{tabular}

The first cash flow statement that was constructed is shown in Figure 4.5 and assumed the time frame of production for the simulated shale gas well to be ten-years. The values for this cash flow statement served as the basis for all subsequent cash flow statements under the different assumptions. 


\begin{tabular}{|c|c|c|c|c|c|}
\hline Year & $\mathbf{0}$ & 1 & 2 & 3 & 4 \\
\hline \multicolumn{6}{|l|}{ Revenues } \\
\hline Production & 0 & $1,112,493$ & 705,498 & 512,248 & 399,910 \\
\hline Price of Natural Gas (\$/mcf) & & 4.04 & 4.12 & 4.21 & 4.30 \\
\hline Gross Receipts & 0 & $4,494,474$ & $2,910,068$ & $2,157,314$ & $1,719,576$ \\
\hline Royalty Payments & 0 & $-764,061$ & $-494,712$ & $-366,743$ & $-292,328$ \\
\hline Net Receipts & $\mathbf{0}$ & $3,730,413$ & $2,415,356$ & $1,790,570$ & $1,427,248$ \\
\hline \multicolumn{6}{|l|}{ Costs: } \\
\hline Lease Operating Costs per Mcf & 0.00 & -0.70 & -0.70 & -0.70 & -0.70 \\
\hline Cash Operating & 0 & $-778,745$ & $-493,849$ & $-358,574$ & $-279,937$ \\
\hline Site Prep and Permitting & $-405,100$ & & & & \\
\hline $\begin{array}{l}\text { Intangible Drilling Costs } \\
\text { Lease Acquisition (5-year } \\
\text { lease) }\end{array}$ & $\begin{array}{l}-3,375,000 \\
-2,208,000\end{array}$ & & & & \\
\hline \multicolumn{6}{|l|}{ Non-cash costs } \\
\hline Cost Based Depletion & 0 & $-1,399,000$ & $-820,600$ & $-565,861$ & $-424,301$ \\
\hline $\begin{array}{l}\text { Tangible Drilling Costs } \\
\text { Depreciation }\end{array}$ & 0 & $-160,650$ & $-275,513$ & $-196,763$ & $-140,513$ \\
\hline Total Costs & $-5,988,100$ & $-2,338,396$ & $-1,589,961$ & $-1,121,197$ & $-844,751$ \\
\hline Taxable Income & $-5,988,100$ & $1,392,017$ & 825,395 & 669,373 & 582,497 \\
\hline Pennsylvania State Taxes & 592,822 & $-137,810$ & $-81,714$ & $-66,268$ & $-57,667$ \\
\hline Federal Taxable Income & $-5,395,278$ & $1,254,207$ & 743,681 & 603,105 & 524,830 \\
\hline Taxes & $1,834,395$ & $-426,431$ & $-252,852$ & $-205,056$ & $-178,442$ \\
\hline Income after Tax & $-3,560,884$ & 827,777 & 490,829 & 398,049 & 346,387 \\
\hline \multicolumn{6}{|l|}{ Cash Flow } \\
\hline After Tax Income & $-3,560,884$ & 827,777 & 490,829 & 398,049 & 346,387 \\
\hline \multicolumn{6}{|l|}{ Non-cash charges } \\
\hline Depreciation & 0 & 160,650 & 275,513 & 196,763 & 140,513 \\
\hline Cost Depletion & 0 & $1,399,000$ & 820,600 & 565,861 & 424,301 \\
\hline \multicolumn{6}{|l|}{ Capital Expenditures } \\
\hline Tangible Drilling Costs & $-1,125,000$ & & & & \\
\hline Net Cash Flow & $-4,685,884$ & $2,387,427$ & $1,586,942$ & $1,160,673$ & 911,201 \\
\hline Present Value @ 10\% & $-4,685,884$ & $2,170,389$ & $1,311,522$ & 872,031 & 622,363 \\
\hline
\end{tabular}

Figure 4.5a 


\begin{tabular}{|c|c|c|c|c|c|c|}
\hline Year & 5 & 6 & 7 & 8 & 9 & 10 \\
\hline \multicolumn{7}{|l|}{ Revenues } \\
\hline Production & 326,742 & 275,445 & 237,570 & 208,508 & 185,536 & 166,941 \\
\hline $\begin{array}{l}\text { Price of Natural Gas } \\
(\$ / \mathrm{mcf})\end{array}$ & 4.39 & 4.48 & 4.58 & 4.67 & 4.77 & 4.87 \\
\hline Gross Receipts & $1,434,464$ & $1,234,653$ & $1,087,245$ & 974,282 & 885,146 & 813,159 \\
\hline Royalty Payments & $-243,859$ & $-209,891$ & $-184,832$ & $-165,628$ & $-150,475$ & $-138,237$ \\
\hline Net Receipts & $1,190,605$ & $1,024,762$ & 902,413 & 808,654 & 734,671 & 674,922 \\
\hline $\begin{array}{l}\text { Costs: } \\
\text { Lease Operating Costs per } \\
\text { Mcf }\end{array}$ & -0.70 & -0.70 & -0.70 & -0.70 & -0.70 & -0.70 \\
\hline Cash Operating & $-228,720$ & $-192,812$ & $-166,299$ & $-145,956$ & $-129,875$ & $-116,859$ \\
\hline \multicolumn{7}{|l|}{ Site Prep and Permitting } \\
\hline $\begin{array}{l}\text { Intangible Drilling Costs } \\
\text { Lease Acquisition (5-year } \\
\text { lease) }\end{array}$ & $-2,208,000$ & & & & & \\
\hline \multicolumn{7}{|l|}{ Non-cash costs } \\
\hline Cost Based Depletion & $-334,723$ & $-272,964$ & $-227,543$ & $-192,146$ & $-162,512$ & $-133,208$ \\
\hline $\begin{array}{l}\text { Tangible Drilling Costs } \\
\text { Depreciation }\end{array}$ & $-100,463$ & $-100,463$ & $-100,463$ & $-50,175$ & & \\
\hline Total Costs & $-2,871,905$ & $-566,238$ & $-494,304$ & $-388,277$ & $-292,387$ & $-250,067$ \\
\hline Taxable Income & $-1,681,300$ & 458,524 & 408,109 & 420,377 & 442,284 & 424,855 \\
\hline Pennsylvania State Taxes & 166,449 & $-45,394$ & $-40,403$ & $-41,617$ & $-43,786$ & $-42,061$ \\
\hline Federal Taxable Income & $-1,514,852$ & 413,130 & 367,706 & 378,760 & 398,498 & 382,795 \\
\hline Taxes & 515,050 & $-140,464$ & $-125,020$ & $-128,778$ & $-135,489$ & $-130,150$ \\
\hline Income after Tax & $-999,802$ & 272,666 & 242,686 & 249,982 & 263,009 & 252,645 \\
\hline \multicolumn{7}{|l|}{ Cash Flow } \\
\hline After Tax Income & $-999,802$ & 272,666 & 242,686 & 249,982 & 263,009 & 252,645 \\
\hline \multicolumn{7}{|l|}{ Non-cash charges } \\
\hline Depreciation & 100,463 & 100,463 & 100,463 & 50,175 & 0 & 0 \\
\hline Cost Depletion & 334,723 & 272,964 & 227,543 & 192,146 & 162,512 & 133,208 \\
\hline \multicolumn{7}{|l|}{ Capital Expenditures } \\
\hline \multicolumn{7}{|l|}{ Tangible Drilling Costs } \\
\hline Net Cash Flow & $-564,616$ & 646,092 & 570,691 & 492,303 & 425,520 & 385,853 \\
\hline Present Value @ 10\% & $-350,582$ & 364,702 & 292,855 & 229,663 & 180,462 & 148,763 \\
\hline
\end{tabular}

Figure $4.5 b$ - Cash flow statement constructed for a shale gas well that produces natural gas for ten years. Production and cost data for years 0 through 4 is shown in part $a$ and years 5 through 10 are shown in part $b$. The production values were calculated from a 
production decline curve that assumed ten years of production for the shale gas well with an initial production rate of 4,000 mcf of natural gas per day and a 70 percent annual decline in production.

The construction of this cash flow statement allows the calculation of the net present value and internal rate of return in order to determine the overall profitability of the well. Table 4.3 shows a summary of the results of the simulated shale gas well under the ten-year assumptions:

Table 4.3

Results from the cash flow statement with ten years of production

\begin{tabular}{|l|l|}
\hline \multicolumn{2}{|c|}{$\begin{array}{c}\text { Summary data for cash flow statement } \\
\text { with 10-years of production }\end{array}$} \\
\hline EUR & 4.14 Bcf \\
\hline NPV & $\$ 1,156,284$ \\
\hline IRR & $19 \%$ \\
\hline
\end{tabular}

Based on the NPV greater than one million dollars and an IRR nearly doubled the MARR of 10 percent, the shale gas well under the assumptions and values used in this analysis was found to be profitable based on ten-years of production. The favorable economics of the simulated well, under the ten-year time frame, was an important finding given the adverse conditions currently facing the shale gas industry. It has been estimated that it takes shale gas wells at least eight to ten years to recoup their investment and this analysis illustrates that given the assumptions made and input values used that ten years worth of production is not only a sufficient amount of time to recoup investment but to also profit considerably from a shale gas well in the Marcellus Shale. 


\subsection{Twenty-year cash flow statement assuming no workovers or re- stimulation}

The second cash flow statement constructed for the analysis assumed the production of the simulated shale gas well would continue past year ten until year twenty. The same initial production and cost input values were utilized, as in the ten-year cash flow statement, and additionally no workover or re-stimulation efforts were assumed to have been done to the well. 


\begin{tabular}{|c|c|c|c|c|c|}
\hline Year & $\mathbf{0}$ & 1 & 2 & 3 & 4 \\
\hline \multicolumn{6}{|l|}{ Revenues } \\
\hline Production & 0 & $1,112,493$ & 705,498 & 512,248 & 399,910 \\
\hline Price of Natural Gas ( $\$ / \mathrm{mcf})$ & & 4.04 & 4.12 & 4.21 & 4.30 \\
\hline Gross Receipts & 0 & $4,494,474$ & $2,910,068$ & $2,157,314$ & $1,719,576$ \\
\hline Royalty Payments & 0 & $-764,061$ & $-494,712$ & $-366,743$ & $-292,328$ \\
\hline Net Receipts & $\mathbf{0}$ & $3,730,413$ & $2,415,356$ & $1,790,570$ & $1,427,248$ \\
\hline \multicolumn{6}{|l|}{ Costs: } \\
\hline Lease Operating Costs per Mcf & 0.00 & -0.70 & -0.70 & -0.70 & -0.70 \\
\hline Cash Operating & 0 & $-778,745$ & $-493,849$ & $-358,574$ & $-279,937$ \\
\hline Site Prep and Permitting & $-405,100$ & & & & \\
\hline Intangible Drilling Costs & $-3,375,000$ & & & & \\
\hline Lease Acquisition (5-year lease) & $-2,208,000$ & & & & \\
\hline \multicolumn{6}{|l|}{ Non-cash costs } \\
\hline Cost Based Depletion & 0 & $-2,042,005$ & $-1,246,213$ & $-884,577$ & $-679,764$ \\
\hline Tangible Drilling Costs Depreciation & 0 & $-160,650$ & $-275,513$ & $-196,763$ & $-140,513$ \\
\hline Total Costs & $-5,988,100$ & $-2,981,400$ & $-2,015,575$ & $-1,439,913$ & $-1,100,213$ \\
\hline Taxable Income & $-5,988,100$ & 749,013 & 399,782 & 350,657 & 327,034 \\
\hline Pennsylvania State Taxes & 592,822 & $-74,152$ & $-39,578$ & $-34,715$ & $-32,376$ \\
\hline Federal Taxable Income & $-5,395,278$ & 674,860 & 360,203 & 315,942 & 294,658 \\
\hline Taxes & $1,834,395$ & $-229,453$ & $-122,469$ & $-107,420$ & $-100,184$ \\
\hline Income after Tax & $-3,560,884$ & 445,408 & 237,734 & 208,522 & 194,474 \\
\hline \multicolumn{6}{|l|}{ Cash Flow } \\
\hline After Tax Income & $-3,560,884$ & 445,408 & 237,734 & 208,522 & 194,474 \\
\hline \multicolumn{6}{|l|}{ Non-cash charges } \\
\hline Depreciation & 0 & 160,650 & 275,513 & 196,763 & 140,513 \\
\hline Cost Depletion & 0 & $2,042,005$ & $1,246,213$ & 884,577 & 679,764 \\
\hline \multicolumn{6}{|l|}{ Capital Expenditures } \\
\hline Tangible Drilling Costs & $-1,125,000$ & & & & \\
\hline Net Cash Flow & $-4,685,884$ & $2,648,063$ & $1,759,460$ & $1,289,861$ & $1,014,750$ \\
\hline Present Value @ 10\% & $-4,685,884$ & $2,407,330$ & $1,454,099$ & 969,092 & 693,088 \\
\hline
\end{tabular}

Figure 4.6a 


\begin{tabular}{|c|c|c|c|c|c|c|}
\hline Year & 5 & 6 & 7 & 8 & 9 & 10 \\
\hline \multicolumn{7}{|l|}{ Revenues } \\
\hline Production & 326,742 & 275,445 & 237,570 & 208,508 & 185,536 & 166,941 \\
\hline $\begin{array}{l}\text { Price of Natural Gas } \\
(\$ / \mathrm{mcf})\end{array}$ & 4.39 & 4.48 & 4.58 & 4.67 & 4.77 & 4.87 \\
\hline Gross Receipts & $1,434,464$ & $1,234,653$ & $1,087,245$ & 974,282 & 885,146 & 813,159 \\
\hline Royalty Payments & $-243,859$ & $-209,891$ & $-184,832$ & $-165,628$ & $-150,475$ & $-138,237$ \\
\hline Net Receipts & $1,190,605$ & $1,024,762$ & 902,413 & 808,654 & 734,671 & 674,922 \\
\hline $\begin{array}{l}\text { Costs: } \\
\text { Lease Operating Costs per } \\
\text { Mcf }\end{array}$ & -0.70 & -0.70 & -0.70 & -0.70 & -0.70 & -0.70 \\
\hline Cash Operating & $-228,720$ & $-192,812$ & $-166,299$ & $-145,956$ & $-129,875$ & $-116,859$ \\
\hline \multicolumn{7}{|l|}{ Site Prep and Permitting } \\
\hline $\begin{array}{l}\text { Intangible Drilling Costs } \\
\text { Lease Acquisition (5-year } \\
\text { lease) }\end{array}$ & $-2,208,000$ & & & & & $-2,208,000$ \\
\hline \multicolumn{7}{|l|}{ Non-cash costs } \\
\hline Cost Based Depletion & $-548,715$ & $-458,030$ & $-391,740$ & $-341,273$ & $-301,626$ & $-269,688$ \\
\hline \multicolumn{7}{|l|}{ Tangible Drilling Costs } \\
\hline Total Costs & $-3,085,897$ & $-751,304$ & $-658,501$ & $-537,403$ & $-431,501$ & $-2,594,546$ \\
\hline Taxable Income & $-1,895,292$ & 273,458 & 243,912 & 271,251 & 303,170 & $-1,919,624$ \\
\hline Pennsylvania State Taxes & 187,634 & $-27,072$ & $-24,147$ & $-26,854$ & $-30,014$ & 190,043 \\
\hline Federal Taxable Income & $-1,707,658$ & 246,386 & 219,765 & 244,397 & 273,156 & $-1,729,581$ \\
\hline Taxes & 580,604 & $-83,771$ & $-74,720$ & $-83,095$ & $-92,873$ & 588,058 \\
\hline Income after Tax & $-1,127,054$ & 162,615 & 145,045 & 161,302 & 180,283 & $-1,141,524$ \\
\hline \multicolumn{7}{|l|}{ Cash Flow } \\
\hline After Tax Income & $-1,127,054$ & 162,615 & 145,045 & 161,302 & 180,283 & $-1,141,524$ \\
\hline \multicolumn{7}{|l|}{ Non-cash charges } \\
\hline Depreciation & 100,463 & 100,463 & 100,463 & 50,175 & 0 & 0 \\
\hline Cost Depletion & 548,715 & 458,030 & 391,740 & 341,273 & 301,626 & 269,688 \\
\hline \multicolumn{7}{|l|}{ Capital Expenditures } \\
\hline \multicolumn{7}{|l|}{ Tangible Drilling Costs } \\
\hline Net Cash Flow & $-477,877$ & 721,107 & 637,247 & $\mathbf{5 5 2 , 7 5 0}$ & 481,909 & $-871,836$ \\
\hline Present Value @ 10\% & $-296,724$ & 407,046 & 327,008 & 257,862 & 204,376 & $-336,131$ \\
\hline
\end{tabular}

Figure 4.6b 


\begin{tabular}{|c|c|c|c|c|c|}
\hline Year & 11 & 12 & 13 & 14 & 15 \\
\hline \multicolumn{6}{|l|}{ Revenues } \\
\hline Production & 151,595 & 138,727 & 127,787 & 118,378 & 110,204 \\
\hline Price of Natural Gas (\$/mcf) & 4.97 & 5.08 & 5.18 & 5.29 & 5.40 \\
\hline Gross Receipts & 753,920 & 704,408 & 662,484 & 626,593 & 595,576 \\
\hline Royalty Payments & $-128,166$ & $-119,749$ & $-112,622$ & $-106,521$ & $-101,248$ \\
\hline Net Receipts & 625,753 & 584,658 & 549,862 & 520,073 & 494,328 \\
\hline \multicolumn{6}{|l|}{ Costs: } \\
\hline Lease Operating Costs per Mcf & -0.70 & -0.70 & -0.70 & -0.70 & -0.70 \\
\hline Cash Operating & $-106,117$ & $-97,109$ & $-89,451$ & $-82,864$ & $-77,143$ \\
\hline \multicolumn{6}{|l|}{ Site Prep and Permitting } \\
\hline \multicolumn{6}{|l|}{ Intangible Drilling Costs } \\
\hline Lease Acquisition (5-year lease) & & & & & $-2,208,000$ \\
\hline \multicolumn{6}{|l|}{ Non-cash costs } \\
\hline Cost Based Depletion & $-243,424$ & $-221,449$ & $-202,785$ & $-186,719$ & $-172,717$ \\
\hline \multicolumn{6}{|l|}{$\begin{array}{l}\text { Tangible Drilling Costs } \\
\text { Depreciation }\end{array}$} \\
\hline Total Costs & $-349,541$ & $-318,558$ & $-292,235$ & $-269,583$ & $-2,457,859$ \\
\hline Taxable Income & 276,212 & 266,100 & 257,627 & 250,489 & $-1,963,531$ \\
\hline Pennsylvania State Taxes & $-27,345$ & $-26,344$ & $-25,505$ & $-24,798$ & 194,390 \\
\hline Federal Taxable Income & 248,867 & 239,757 & 232,121 & 225,691 & $-1,769,141$ \\
\hline Taxes & $-80,308$ & $-76,755$ & $-73,777$ & $-71,269$ & 601,508 \\
\hline Income after Tax & 168,559 & 163,001 & 158,344 & 154,421 & $-1,167,633$ \\
\hline \multicolumn{6}{|l|}{ Cash Flow } \\
\hline After Tax Income & 168,559 & 163,001 & 158,344 & 154,421 & $-1,167,633$ \\
\hline \multicolumn{6}{|l|}{ Non-cash charges } \\
\hline Depreciation & 0 & 0 & 0 & 0 & 0 \\
\hline Cost Depletion & 243,424 & 221,449 & 202,785 & 186,719 & 172,717 \\
\hline \multicolumn{6}{|l|}{ Capital Expenditures } \\
\hline \multicolumn{6}{|l|}{ Tangible Drilling Costs } \\
\hline Net Cash Flow & 411,983 & 384,451 & 361,129 & 341,140 & $-994,916$ \\
\hline Present Value @ 10\% & 144,398 & 122,498 & 104,606 & 89,833 & $-238,175$ \\
\hline
\end{tabular}

Figure 4.6c 


\begin{tabular}{|c|c|c|c|c|c|}
\hline Year & 16 & 17 & 18 & 19 & 20 \\
\hline \multicolumn{6}{|l|}{ Revenues } \\
\hline Production & 103,039 & 96,711 & 91,083 & 86,047 & 81,514 \\
\hline Price of Natural Gas (\$/mcf) & 5.52 & 5.63 & 5.75 & 5.87 & 6.00 \\
\hline Gross Receipts & 568,553 & 544,843 & 523,911 & 505,334 & 488,768 \\
\hline Royalty Payments & $-96,654$ & $-92,623$ & $-89,065$ & $-85,907$ & $-83,091$ \\
\hline Net Receipts & 471,899 & 452,219 & 434,846 & 419,427 & 405,678 \\
\hline \multicolumn{6}{|l|}{ Costs: } \\
\hline Lease Operating Costs per Mcf & -0.70 & -0.70 & -0.70 & -0.70 & -0.70 \\
\hline Cash Operating & $-72,128$ & $-67,698$ & $-63,758$ & $-60,233$ & $-57,060$ \\
\hline \multicolumn{6}{|l|}{ Site Prep and Permitting } \\
\hline \multicolumn{6}{|l|}{ Intangible Drilling Costs } \\
\hline \multicolumn{6}{|l|}{ Lease Acquisition (5-year lease) } \\
\hline \multicolumn{6}{|l|}{ Non-cash costs } \\
\hline Cost Based Depletion & $-160,361$ & $-149,308$ & $-139,231$ & $-129,721$ & $-119,716$ \\
\hline \multicolumn{6}{|l|}{$\begin{array}{l}\text { Tangible Drilling Costs } \\
\text { Depreciation }\end{array}$} \\
\hline Total Costs & $-232,489$ & $-217,006$ & $-202,989$ & $-189,954$ & $-176,775$ \\
\hline Taxable Income & 239,410 & 235,214 & 231,857 & 229,473 & 228,902 \\
\hline Pennsylvania State Taxes & $-23,702$ & $-23,286$ & $-22,954$ & $-22,718$ & $-22,661$ \\
\hline Federal Taxable Income & 215,708 & 211,928 & 208,903 & 206,755 & 206,241 \\
\hline Taxes & $-67,376$ & $-65,902$ & $-64,722$ & $-63,885$ & $-63,684$ \\
\hline Income after Tax & 148,332 & 146,026 & 144,181 & 142,871 & 142,557 \\
\hline \multicolumn{6}{|l|}{ Cash Flow } \\
\hline After Tax Income & 148,332 & 146,026 & 144,181 & 142,871 & 142,557 \\
\hline \multicolumn{6}{|l|}{ Non-cash charges } \\
\hline Depreciation & 0 & 0 & 0 & 0 & 0 \\
\hline Cost Depletion & 160,361 & 149,308 & 139,231 & 129,721 & 119,716 \\
\hline \multicolumn{6}{|l|}{ Capital Expenditures } \\
\hline \multicolumn{6}{|l|}{ Tangible Drilling Costs } \\
\hline Net Cash Flow & 308,694 & 295,333 & 283,412 & 272,592 & 262,273 \\
\hline Present Value @ 10\% & 67,181 & 58,430 & 50,974 & 44,571 & 38,985 \\
\hline
\end{tabular}

Figure 4.6d - Cash flow statement constructed for a shale gas well that produces natural gas for twenty years with no assumed workovers or re-stimulation activities having been completed. Production and cost data for years 0 through 4 are shown in part $a, 5$ through 
10 in part $b$, years 11 through 15 in part $c$, and years 16 through 20 in part $d$. The production values for the cash flow statement were calculated based on a shale gas well that produced natural gas for twenty years with an initial rate of production of 4,000 mcf of natural gas per day and an annual production decline rate of 70 percent.

After discovering the shale gas well could be considered profitable after ten-years of production it was then expected that if the well were able to keep producing gas for an additional ten years that the NPV and IRR values would increase and the well would be more profitable. The cash flow statement assuming no workover or re-stimulation efforts did in fact prove that the simulated shale gas well was still profitable under the new assumptions of longer production. Table 4.4 shows the values calculated for the NPV and IRR of the net cash flows:

Table 4.4

Results from the cash flow statement with twenty years of natural gas production

\begin{tabular}{|l|l|}
\hline \multicolumn{2}{|c|}{$\begin{array}{c}\text { Summary data for cash flow statement } \\
\text { of } 20 \text { years of production }\end{array}$} \\
\hline EUR & 5.24 Bcf \\
\hline NPV & $\$ 1,884,464$ \\
\hline IRR & $24 \%$ \\
\hline
\end{tabular}

As a result of letting the well produce natural gas until year twenty there was an addition of $\$ 728,181$ in net present value and a gain of 5 percent return for the IRR. These results indicate that if the assumptions for lease bonus payments, royalty rates and lease operating costs remain constant after year ten that it would be financially beneficial for a producer to keep a shale gas well in the Marcellus Shale producing for twenty years. 


\subsection{Twenty-year cash flow statement with workovers and re- stimulation efforts included}

As was stated in the previous chapter, producers have the ability to increase the productivity of a shale gas well through workover and re-stimulation efforts. These activities include such actions as recasing the well and additional stages of hydraulic fracturing (Oilgasglossary.com 2012). To perform workovers and re-stimulate the well costs the producer a significant amount of money. This analysis assumed that amount to be 60 percent of the original drilling and completion costs or a total monetary value of $\$ 3,375,000$. Additionally, the analysis assumed that as a result of the workover and restimulation, the production rate of the well would increase to 40 percent of the original rate of production after year ten. All of the other initial input values however, relating to production and costs variables were kept the same. The cash flow statement shown in Figure 4.7 was constructed based on the assumptions of twenty-years of production with workovers and re-stimulation efforts performed to the well in year ten. 


\begin{tabular}{|c|c|c|c|c|c|}
\hline Year & $\mathbf{0}$ & 1 & 2 & 3 & 4 \\
\hline \multicolumn{6}{|l|}{ Revenues } \\
\hline Production & 0 & $1,112,493$ & 705,498 & 512,248 & 399,910 \\
\hline Price of Natural Gas (\$/mcf) & & 4.04 & 4.12 & 4.21 & 4.30 \\
\hline Gross Receipts & 0 & $4,494,474$ & $2,910,068$ & $2,157,314$ & $1,719,576$ \\
\hline Royalty Payments & 0 & $-764,061$ & $-494,712$ & $-366,743$ & $-292,328$ \\
\hline Net Receipts & $\mathbf{0}$ & $3,730,413$ & $2,415,356$ & $1,790,570$ & $1,427,248$ \\
\hline \multicolumn{6}{|l|}{ Costs: } \\
\hline Lease Operating Costs per Mcf & 0.00 & -0.70 & -0.70 & -0.70 & -0.70 \\
\hline Cash Operating & 0 & $-778,745$ & $-493,849$ & $-358,574$ & $-279,937$ \\
\hline Site Prep and Permitting & $-405,100$ & & & & \\
\hline Intangible Drilling Costs & $-3,375,000$ & & & & \\
\hline Lease Acquisition (5-year lease) & $-2,208,000$ & & & & \\
\hline \multicolumn{6}{|l|}{ Non-cash costs } \\
\hline Cost Based Depletion & 0 & $-1,846,258$ & $-1,127,862$ & $-801,477$ & $-616,624$ \\
\hline Tangible Drilling Costs Depreciation & 0 & $-160,650$ & $-275,513$ & $-196,763$ & $-140,513$ \\
\hline Total Costs & $-5,988,100$ & $-2,785,653$ & $-1,897,223$ & $-1,356,813$ & $-1,037,074$ \\
\hline Taxable Income & $-5,988,100$ & 944,760 & 518,133 & 433,757 & 390,174 \\
\hline Pennsylvania State Taxes & 592,822 & $-93,531$ & $-51,295$ & $-42,942$ & $-38,627$ \\
\hline Federal Taxable Income & $-5,395,278$ & 851,229 & 466,838 & 390,815 & 351,547 \\
\hline Taxes & $1,834,395$ & $-289,418$ & $-158,725$ & $-132,877$ & $-119,526$ \\
\hline Income after Tax & $-3,560,884$ & 561,811 & 308,113 & 257,938 & 232,021 \\
\hline \multicolumn{6}{|l|}{ Cash Flow } \\
\hline After Tax Income & $-3,560,884$ & 561,811 & 308,113 & 257,938 & 232,021 \\
\hline \multicolumn{6}{|l|}{ Non-cash charges } \\
\hline Depreciation & 0 & 160,650 & 275,513 & 196,763 & 140,513 \\
\hline Cost Depletion & 0 & $1,846,258$ & $1,127,862$ & 801,477 & 616,624 \\
\hline \multicolumn{6}{|l|}{ Capital Expenditures } \\
\hline Tangible Drilling Costs & $-1,125,000$ & & & & \\
\hline Net Cash Flow & $-4,685,884$ & 2,568,719 & $1,711,487$ & $1,256,178$ & 989,157 \\
\hline Present Value @ 10\% & $-4,685,884$ & $2,335,199$ & $1,414,452$ & 943,785 & 675,608 \\
\hline
\end{tabular}

Figure $4.7 \mathrm{a}$ 


\begin{tabular}{|c|c|c|c|c|c|c|}
\hline Year & 5 & 6 & 7 & 8 & 9 & 10 \\
\hline \multicolumn{7}{|l|}{ Revenues } \\
\hline Production & 326,742 & 275,445 & 237,570 & 208,508 & 185,536 & 166,941 \\
\hline $\begin{array}{l}\text { Price of Natural Gas } \\
(\$ / \mathrm{mcf})\end{array}$ & 4.39 & 4.48 & 4.58 & 4.67 & 4.77 & 4.87 \\
\hline Gross Receipts & $1,434,464$ & $1,234,653$ & $1,087,245$ & 974,282 & 885,146 & 813,159 \\
\hline Royalty Payments & $-243,859$ & $-209,891$ & $-184,832$ & $-165,628$ & $-150,475$ & $-138,237$ \\
\hline Net Receipts & $1,190,605$ & $1,024,762$ & 902,413 & 808,654 & 734,671 & 674,922 \\
\hline $\begin{array}{l}\text { Costs: } \\
\text { Lease Operating Costs per } \\
\text { Mcf }\end{array}$ & -0.70 & -0.70 & -0.70 & -0.70 & -0.70 & -0.70 \\
\hline Cash Operating & $-228,720$ & $-192,812$ & $-166,299$ & $-145,956$ & $-129,875$ & $-116,859$ \\
\hline \multicolumn{7}{|l|}{ Site Prep and Permitting } \\
\hline $\begin{array}{l}\text { Intangible Drilling Costs } \\
\text { Lease Acquisition (5-year } \\
\text { lease) }\end{array}$ & $-2,208,000$ & & & & & $\begin{array}{l}-3,375,000 \\
-2,208,000\end{array}$ \\
\hline \multicolumn{7}{|l|}{ Non-cash costs } \\
\hline Cost Based Depletion & $-498,338$ & $-416,484$ & $-356,654$ & $-311,115$ & $-275,355$ & $-246,569$ \\
\hline $\begin{array}{l}\text { Tangible Drilling Costs } \\
\text { Depreciation }\end{array}$ & $-100,463$ & $-100,463$ & $-100,463$ & $-50,175$ & & \\
\hline Total Costs & $-3,035,520$ & $-709,758$ & $-623,415$ & $-507,246$ & $-405,230$ & $-5,946,428$ \\
\hline Taxable Income & $-1,844,915$ & 315,004 & 278,998 & 301,409 & 329,441 & $-5,271,506$ \\
\hline Pennsylvania State Taxes & 182,647 & $-31,185$ & $-27,621$ & $-29,839$ & $-32,615$ & 521,879 \\
\hline Federal Taxable Income & $-1,662,269$ & 283,819 & 251,377 & 271,569 & 296,826 & $-4,749,626$ \\
\hline Taxes & 565,171 & $-93,939$ & $-81,287$ & $-89,162$ & $-99,012$ & $1,614,873$ \\
\hline Income after Tax & $-1,097,097$ & 189,880 & 170,090 & 182,407 & 197,814 & $-3,134,753$ \\
\hline \multicolumn{7}{|l|}{ Cash Flow } \\
\hline After Tax Income & $-1,097,097$ & 189,880 & 170,090 & 182,407 & 197,814 & $-3,134,753$ \\
\hline \multicolumn{7}{|l|}{ Non-cash charges } \\
\hline Depreciation & 100,463 & 100,463 & 100,463 & 50,175 & 0 & 0 \\
\hline Cost Depletion & 498,338 & 416,484 & 356,654 & 311,115 & 275,355 & 246,569 \\
\hline \multicolumn{7}{|l|}{ Capital Expenditures } \\
\hline Tangible Drilling Costs & & & & & & 0 \\
\hline Net Cash Flow & $-498,296$ & 706,826 & 627,206 & 543,697 & 473,169 & $-2,888,184$ \\
\hline Present Value @ 10\% & $-309,403$ & 398,985 & 321,856 & 253,639 & 200,670 & $-1,113,520$ \\
\hline
\end{tabular}

Figure 4.7b 


\begin{tabular}{|c|c|c|c|c|c|}
\hline Year & 11 & 12 & 13 & 14 & 15 \\
\hline \multicolumn{6}{|l|}{ Revenues } \\
\hline Production & 429,253 & 291,212 & 209,747 & 162,973 & 132,738 \\
\hline Price of Natural Gas (\$/mcf) & 4.97 & 5.08 & 5.18 & 5.29 & 5.40 \\
\hline Gross Receipts & $2,134,774$ & $1,478,678$ & $1,087,390$ & 862,644 & 717,361 \\
\hline Royalty Payments & $-362,912$ & $-251,375$ & $-184,856$ & $-146,649$ & $-121,951$ \\
\hline Net Receipts & $\mathbf{1 , 7 7 1 , 8 6 3}$ & $1,227,302$ & 902,533 & 715,994 & 595,409 \\
\hline \multicolumn{6}{|l|}{ Costs: } \\
\hline Lease Operating Costs per Mcf & -0.70 & -0.70 & -0.70 & -0.70 & -0.70 \\
\hline Cash Operating & $-300,477$ & $-203,848$ & $-146,823$ & $-114,081$ & $-92,917$ \\
\hline \multicolumn{6}{|l|}{ Site Prep and Permitting } \\
\hline \multicolumn{6}{|l|}{ Intangible Drilling Costs } \\
\hline Lease Acquisition (5-year lease) & & & & & $-2,208,000$ \\
\hline \multicolumn{6}{|l|}{ Non-cash costs } \\
\hline Cost Based Depletion & $-681,475$ & $-439,463$ & $-303,798$ & $-228,741$ & $-181,351$ \\
\hline Tangible Drilling Costs Depreciation & 0 & 0 & 0 & 0 & 0 \\
\hline Total Costs & $-981,952$ & $-643,312$ & $-450,620$ & $-342,822$ & $-2,482,267$ \\
\hline Taxable Income & 789,911 & 583,991 & 451,913 & 373,172 & $-1,886,858$ \\
\hline Pennsylvania State Taxes & $-78,201$ & $-57,815$ & $-44,739$ & $-36,944$ & 186,799 \\
\hline Federal Taxable Income & 711,710 & 526,176 & 407,174 & 336,228 & $-1,700,059$ \\
\hline Taxes & $-241,981$ & $-178,900$ & $-138,439$ & $-114,318$ & 578,020 \\
\hline Income after Tax & 469,728 & 347,276 & 268,735 & 221,911 & $-1,122,039$ \\
\hline \multicolumn{6}{|l|}{ Cash Flow } \\
\hline After Tax Income & 469,728 & 347,276 & 268,735 & 221,911 & $-1,122,039$ \\
\hline \multicolumn{6}{|l|}{ Non-cash charges } \\
\hline Depreciation & 0 & 0 & 0 & 0 & 0 \\
\hline Cost Depletion & 681,475 & 439,463 & 303,798 & 228,741 & 181,351 \\
\hline \multicolumn{6}{|l|}{ Capital Expenditures } \\
\hline \multicolumn{6}{|l|}{ Tangible Drilling Costs } \\
\hline Net Cash Flow & $1,151,203$ & 786,739 & 572,532 & 450,652 & $-940,688$ \\
\hline Present Value @ 10\% & 403,490 & 250,679 & 165,842 & 118,671 & $-225,193$ \\
\hline
\end{tabular}

Figure 4.7c 


\begin{tabular}{|c|c|c|c|c|c|}
\hline Year & 16 & 17 & 18 & 19 & 20 \\
\hline \multicolumn{6}{|l|}{ Revenues } \\
\hline Production & 111,650 & 96,137 & 84,267 & 74,906 & 67,341 \\
\hline Price of Natural Gas (\$/mcf) & 5.52 & 5.63 & 5.75 & 5.87 & 6.00 \\
\hline Gross Receipts & 616,062 & 541,605 & 484,706 & 439,905 & 403,787 \\
\hline Royalty Payments & $-104,731$ & $-92,073$ & $-82,400$ & $-74,784$ & $-68,644$ \\
\hline Net Receipts & 511,331 & 449,532 & 402,306 & 365,121 & 335,143 \\
\hline \multicolumn{6}{|l|}{ Costs: } \\
\hline Lease Operating Costs per Mcf & -0.70 & -0.70 & -0.70 & -0.70 & -0.70 \\
\hline Cash Operating & $-78,155$ & $-67,296$ & $-58,987$ & $-52,434$ & $-47,139$ \\
\hline \multicolumn{6}{|l|}{ Site Prep and Permitting } \\
\hline \multicolumn{6}{|l|}{ Intangible Drilling Costs } \\
\hline \multicolumn{6}{|l|}{ Lease Acquisition (5-year lease) } \\
\hline \multicolumn{6}{|l|}{ Non-cash costs } \\
\hline Cost Based Depletion & $-148,744$ & $-124,842$ & $-106,337$ & $-91,073$ & $-76,581$ \\
\hline Tangible Drilling Costs Depreciation & 0 & 0 & 0 & & \\
\hline Total Costs & $-226,899$ & $-192,137$ & $-165,324$ & $-143,507$ & $-123,720$ \\
\hline Taxable Income & 284,433 & 257,395 & 236,981 & 221,614 & 211,423 \\
\hline Pennsylvania State Taxes & $-28,159$ & $-25,482$ & $-23,461$ & $-21,940$ & $-20,931$ \\
\hline Federal Taxable Income & 256,274 & 231,913 & 213,520 & 199,675 & 190,492 \\
\hline Taxes & $-83,197$ & $-73,696$ & $-66,523$ & $-61,123$ & $-57,542$ \\
\hline Income after Tax & 173,077 & 158,217 & 146,997 & 138,552 & 132,950 \\
\hline \multicolumn{6}{|l|}{ Cash Flow } \\
\hline After Tax Income & 173,077 & 158,217 & 146,997 & 138,552 & 132,950 \\
\hline \multicolumn{6}{|l|}{ Non-cash charges } \\
\hline Depreciation & 0 & 0 & 0 & 0 & 0 \\
\hline Cost Depletion & 148,744 & 124,842 & 106,337 & 91,073 & 76,581 \\
\hline \multicolumn{6}{|l|}{ Capital Expenditures } \\
\hline \multicolumn{6}{|l|}{ Tangible Drilling Costs } \\
\hline Net Cash Flow & 321,821 & 283,058 & 253,334 & 229,624 & 209,531 \\
\hline Present Value @ 10\% & 70,038 & 56,002 & 45,564 & 37,545 & 31,146 \\
\hline
\end{tabular}

Figure $4.7 \mathrm{~d}$ - Cash flow statement constructed for a shale gas well that produces natural gas for twenty years with the assumption that workovers and re-stimulation activities were completed in year ten. Production and cost data for years 0 through 4 are shown in 
part $a, 5$ through 10 in part $b$, years 11 through 15 in part $c$, and years 16 through 20 in part $d$. The production values used for this cash flow statement were calculated from a production decline curve that assumed twenty years of production with an initial rate of production of 4,000 mcf of natural gas per day, an annual production decline of 70 percent and that workovers and re-stimulation efforts would be completed in year ten to increase production to a rate that was 40 percent of the original daily rate of production.

One of the issues producers face if they choose to try to increase the productivity of the well is that the gains in production have to be great enough to offset the costs required to achieve those production increases. Furthermore, even after the increases in production are achieved, the shale gas well will still suffer from declines in productivity as was seen in Figure 4.3. Given the assumptions made regarding the costs of the workovers and re-stimulation of the shale gas well in year ten, the increase in production by 40 percent of the original rate of production resulted in an overall profitable well. The results of the NPV and IRR calculations for twenty-year cash flow assuming workover and re-stimulation efforts are shown in Table 4.5:

Table 4.5

Results from the cash flow statement with twenty years of production including workovers and re-stimulation efforts

\begin{tabular}{|l|l|}
\hline \multicolumn{2}{|c|}{$\begin{array}{c}\text { Summary data for cash flow cash flow statement with twenty } \\
\text { years of production including workovers and re-stimulation } \\
\text { efforts }\end{array}$} \\
\hline EUR & $5.78 \mathrm{Bcf}$ \\
\hline NPV & $\$ 1,389,170$ \\
\hline IRR & $21 \%$ \\
\hline
\end{tabular}

The resulting net present value and internal rate of return calculated for this cash flow statement were both within the ranges for the well to be considered profitable. These results serve as another indication that it would be economically favorable for a 
producer to keep a shale gas well in the Marcellus Shale producing past ten years given the assumptions made regarding costs and production increases resulting from workovers and re-stimulation efforts.

\subsection{Cash flow statement with the assumption a shale gas well is drilled in year zero and year ten}

In addition to the ten-year and two twenty-year cash flow statements that were created, a fourth cash flow statement shown in Figure 4.8 was constructed to show the results of a new well being drilled in year ten. For NPV values to be compared directly the cash flow statements have to have a common time frame and by drilling two shale gas wells that each produced natural gas for ten years the cash flow statement could be compared to the other cash flow statements that assumed twenty years of production. The new well drilled in year ten assumed all of the cost and production values to remain the same as the well that was drilled and produced gas the first ten years. The price of natural gas however continued to increase from the year ten values assuming a 2.1 percent annual increase. 


\begin{tabular}{|c|c|c|c|c|c|}
\hline Year & $\mathbf{0}$ & 1 & 2 & 3 & 4 \\
\hline \multicolumn{6}{|l|}{ Revenues } \\
\hline Production & 0 & $1,112,493$ & 705,498 & 512,248 & 399,910 \\
\hline Price of Natural Gas (\$/mcf) & & 4.04 & 4.12 & 4.21 & 4.30 \\
\hline Gross Receipts & 0 & $4,494,474$ & $2,910,068$ & $2,157,314$ & $1,719,576$ \\
\hline Royalty Payments & 0 & $-764,061$ & $-494,712$ & $-366,743$ & $-292,328$ \\
\hline Net Receipts & $\mathbf{0}$ & $3,730,413$ & $2,415,356$ & $1,790,570$ & $1,427,248$ \\
\hline \multicolumn{6}{|l|}{ Costs: } \\
\hline Lease Operating Costs per Mcf & 0.00 & -0.70 & -0.70 & -0.70 & -0.70 \\
\hline Cash Operating & 0 & $-778,745$ & $-493,849$ & $-358,574$ & $-279,937$ \\
\hline Site Prep and Permitting & $-405,100$ & & & & \\
\hline $\begin{array}{l}\text { Intangible Drilling Costs } \\
\text { Lease Acquisition (5-year } \\
\text { lease) }\end{array}$ & $\begin{array}{l}-3,375,000 \\
-2,208,000\end{array}$ & & & & \\
\hline \multicolumn{6}{|l|}{ Non-cash costs } \\
\hline Cost Based Depletion & 0 & $-1,399,000$ & $-820,600$ & $-565,861$ & $-424,301$ \\
\hline $\begin{array}{l}\text { Tangible Drilling Costs } \\
\text { Depreciation }\end{array}$ & 0 & $-160,650$ & $-275,513$ & $-196,763$ & $-140,513$ \\
\hline Total Costs & $-5,988,100$ & $-2,338,396$ & $-1,589,961$ & $-1,121,197$ & $-844,751$ \\
\hline Taxable Income & $-5,988,100$ & $1,392,017$ & 825,395 & 669,373 & 582,497 \\
\hline Pennsylvania State Taxes & 592,822 & $-137,810$ & $-81,714$ & $-66,268$ & $-57,667$ \\
\hline Federal Taxable Income & $-5,395,278$ & $1,254,207$ & 743,681 & 603,105 & 524,830 \\
\hline Taxes & $1,834,395$ & $-426,431$ & $-252,852$ & $-205,056$ & $-178,442$ \\
\hline Income after Tax & $-3,560,884$ & 827,777 & 490,829 & 398,049 & 346,387 \\
\hline \multicolumn{6}{|l|}{ Cash Flow } \\
\hline After Tax Income & $-3,560,884$ & 827,777 & 490,829 & 398,049 & 346,387 \\
\hline \multicolumn{6}{|l|}{ Non-cash charges } \\
\hline Depreciation & 0 & 160,650 & 275,513 & 196,763 & 140,513 \\
\hline Cost Depletion & 0 & $1,399,000$ & 820,600 & 565,861 & 424,301 \\
\hline \multicolumn{6}{|l|}{ Capital Expenditures } \\
\hline Tangible Drilling Costs & $-1,125,000$ & & & & \\
\hline Net Cash Flow & $-4,685,884$ & $2,387,427$ & $1,586,942$ & $1,160,673$ & 911,201 \\
\hline Present Value @ 10\% & $-4,685,884$ & $2,170,389$ & $1,311,522$ & 872,031 & 622,363 \\
\hline
\end{tabular}

Figure 4.8a 


\begin{tabular}{|c|c|c|c|c|c|c|}
\hline Year & 5 & 6 & 7 & 8 & 9 & 10 \\
\hline \multicolumn{7}{|l|}{ Revenues } \\
\hline Production & 326,742 & 275,445 & 237,570 & 208,508 & 185,536 & 166,941 \\
\hline $\begin{array}{l}\text { Price of Natural Gas } \\
(\$ / \mathrm{mcf})\end{array}$ & 4.39 & 4.48 & 4.58 & 4.67 & 4.77 & 4.87 \\
\hline Gross Receipts & $1,434,464$ & $1,234,653$ & $1,087,245$ & 974,282 & 885,146 & 813,159 \\
\hline Royalty Payments & $-243,859$ & $-209,891$ & $-184,832$ & $-165,628$ & $-150,475$ & $-138,237$ \\
\hline Net Receipts & $1,190,605$ & $1,024,762$ & 902,413 & 808,654 & 734,671 & 674,922 \\
\hline $\begin{array}{l}\text { Costs: } \\
\text { Lease Operating Costs } \\
\text { per Mcf }\end{array}$ & -0.70 & -0.70 & -0.70 & -0.70 & -0.70 & -0.70 \\
\hline Cash Operating & $-228,720$ & $-192,812$ & $-166,299$ & $-145,956$ & $-129,875$ & $-116,859$ \\
\hline Site Prep and Permitting & & & & & & $-405,100$ \\
\hline $\begin{array}{l}\text { Intangible Drilling Costs } \\
\text { Lease Acquisition (5-year } \\
\text { lease) }\end{array}$ & $-2,208,000$ & & & & & $\begin{array}{l}-3,375,000 \\
-2,208,000\end{array}$ \\
\hline \multicolumn{7}{|l|}{ Non-cash costs } \\
\hline Cost Based Depletion & $-334,723$ & $-272,964$ & $-227,543$ & $-192,146$ & $-162,512$ & $-133,208$ \\
\hline $\begin{array}{l}\text { Tangible Drilling Costs } \\
\text { Depreciation }\end{array}$ & $-100,463$ & $-100,463$ & $-100,463$ & $-50,175$ & & \\
\hline Total Costs & $-2,871,905$ & $-566,238$ & $-494,304$ & $-388,277$ & $-292,387$ & $-6,238,167$ \\
\hline Taxable Income & $-1,681,300$ & 458,524 & 408,109 & 420,377 & 442,284 & $-5,563,245$ \\
\hline Pennsylvania State Taxes & 166,449 & $-45,394$ & $-40,403$ & $-41,617$ & $-43,786$ & 550,761 \\
\hline Federal Taxable Income & $-1,514,852$ & 413,130 & 367,706 & 378,760 & 398,498 & $-5,012,483$ \\
\hline Taxes & 515,050 & $-140,464$ & $-125,020$ & $-128,778$ & $-135,489$ & $1,704,244$ \\
\hline Income after Tax & $-999,802$ & 272,666 & 242,686 & 249,982 & 263,009 & $-3,308,239$ \\
\hline \multicolumn{7}{|l|}{ Cash Flow } \\
\hline After Tax Income & $-999,802$ & 272,666 & 242,686 & 249,982 & 263,009 & $-3,308,239$ \\
\hline \multicolumn{7}{|l|}{ Non-cash charges } \\
\hline Depreciation & 100,463 & 100,463 & 100,463 & 50,175 & 0 & 0 \\
\hline Cost Depletion & 334,723 & 272,964 & 227,543 & 192,146 & 162,512 & 133,208 \\
\hline \multicolumn{7}{|l|}{ Capital Expenditures } \\
\hline Tangible Drilling Costs & & & & & & $-1,125,000$ \\
\hline Net Cash Flow & $-564,616$ & 646,092 & 570,691 & 492,303 & 425,520 & $-4,300,031$ \\
\hline Present Value @ 10\% & $-350,582$ & 364,702 & 292,855 & 229,663 & 180,462 & $-1,657,848$ \\
\hline
\end{tabular}

Figure 4.8b 


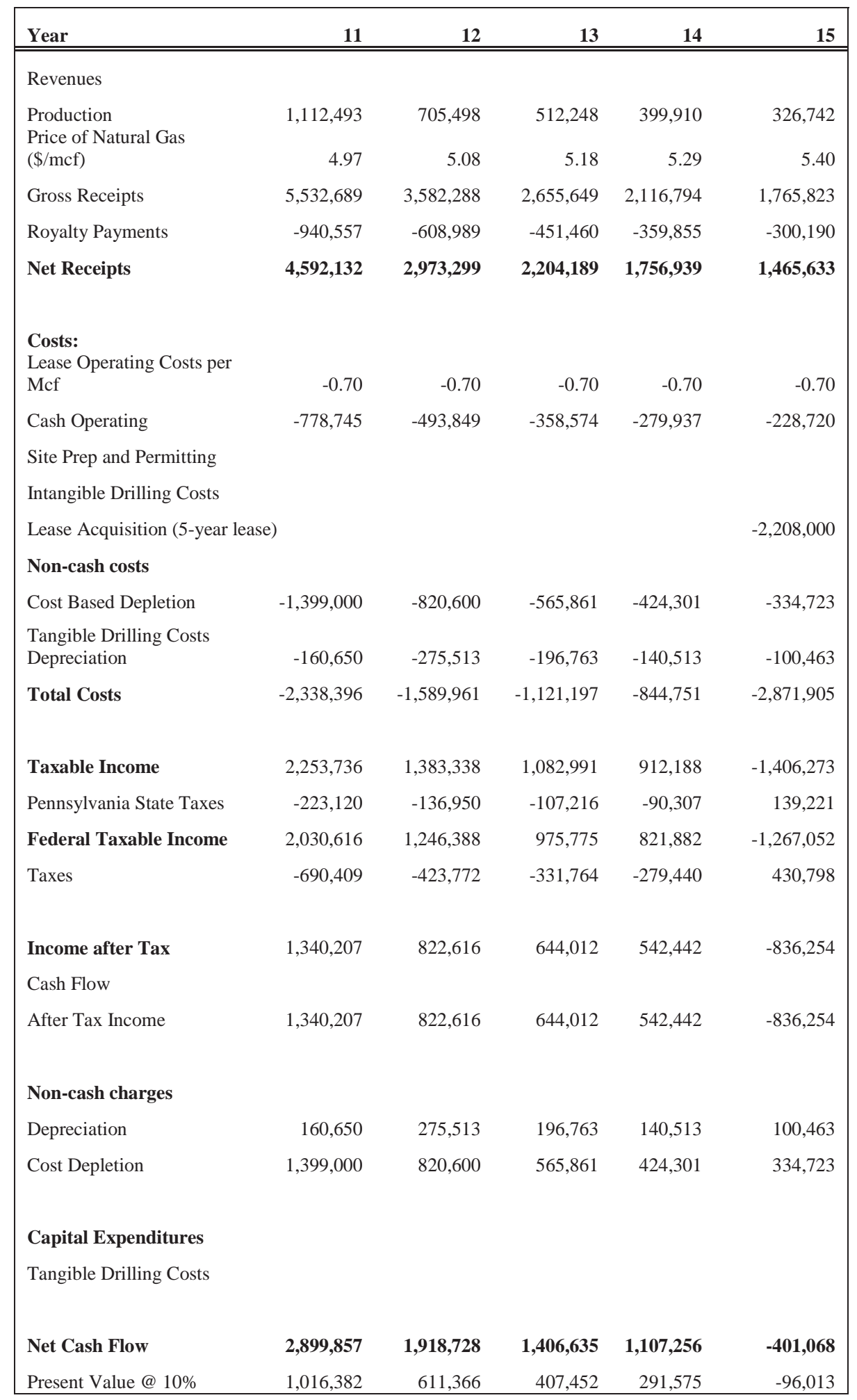

Figure 4.8c 


\begin{tabular}{|c|c|c|c|c|c|}
\hline Year & 16 & 17 & 18 & 19 & 20 \\
\hline \multicolumn{6}{|l|}{ Revenues } \\
\hline Production & 275,445 & 237,570 & 208,508 & 185,536 & 166,941 \\
\hline $\begin{array}{l}\text { Price of Natural Gas } \\
(\$ / \mathrm{mcf})\end{array}$ & 5.52 & 5.63 & 5.75 & 5.87 & 6.00 \\
\hline Gross Receipts & $1,519,856$ & $1,338,397$ & $1,199,340$ & $1,089,613$ & $1,000,997$ \\
\hline Royalty Payments & $-258,376$ & $-227,527$ & $-203,888$ & $-185,234$ & $-170,170$ \\
\hline Net Receipts & $1,261,480$ & $1,110,869$ & 995,452 & 904,378 & 830,828 \\
\hline $\begin{array}{l}\text { Costs: } \\
\text { Lease Operating Costs per } \\
\text { Mcf }\end{array}$ & -0.70 & -0.70 & -0.70 & -0.70 & -0.70 \\
\hline Cash Operating & $-192,812$ & $-166,299$ & $-145,956$ & $-129,875$ & $-116,859$ \\
\hline \multicolumn{6}{|l|}{ Site Prep and Permitting } \\
\hline \multicolumn{6}{|l|}{ Intangible Drilling Costs } \\
\hline \multicolumn{6}{|c|}{ Lease Acquisition (5-year lease) } \\
\hline \multicolumn{6}{|l|}{ Non-cash costs } \\
\hline Cost Based Depletion & $-272,964$ & $-227,543$ & $-192,146$ & $-162,512$ & $-133,208$ \\
\hline \multicolumn{6}{|l|}{ Tangible Drilling Costs } \\
\hline Total Costs & $-566,238$ & $-494,304$ & $-388,277$ & $-292,387$ & $-250,067$ \\
\hline Taxable Income & 695,243 & 616,565 & 607,175 & 611,992 & 580,761 \\
\hline Pennsylvania State Taxes & $-68,829$ & $-61,040$ & $-60,110$ & $-60,587$ & $-57,495$ \\
\hline Federal Taxable Income & 626,414 & 555,525 & 547,065 & 551,405 & 523,266 \\
\hline Taxes & $-212,981$ & $-188,879$ & $-186,002$ & $-187,478$ & $-177,910$ \\
\hline Income after Tax & 413,433 & 366,647 & 361,063 & 363,927 & 345,355 \\
\hline \multicolumn{6}{|l|}{ Cash Flow } \\
\hline After Tax Income & 413,433 & 366,647 & 361,063 & 363,927 & 345,355 \\
\hline \multicolumn{6}{|l|}{ Non-cash charges } \\
\hline Depreciation & 100,463 & 100,463 & 50,175 & 0 & 0 \\
\hline Cost Depletion & 272,964 & 227,543 & 192,146 & 162,512 & 133,208 \\
\hline \multicolumn{6}{|l|}{ Capital Expenditures } \\
\hline \multicolumn{6}{|l|}{ Tangible Drilling Costs } \\
\hline Net Cash Flow & 786,859 & 694,652 & 603,384 & 526,439 & 478,564 \\
\hline Present Value @ 10\% & 171,244 & 137,433 & 108,524 & 86,077 & 71,135 \\
\hline
\end{tabular}

Figure 4.8d - Twenty year cash flow statement constructed for a shale gas well that produces natural gas for ten years with an additional shale gas well being drilled in year ten and producing natural gas for years 11 through 20. Production and cost data for years 
0 through 4 are shown in part $a, 5$ through 10 in part $b$, years 11 through 15 in part $c$, and years 16 through 20 in part $d$. Each of the shale gas wells that were assumed to have been drilled used production values that were calculated from production decline curves with initial rates of production of 4,000 mcf of natural gas per day and annual declines in production of 70 percent.

The results of the cash flow statement that assumed a new shale gas well would be drilled in year ten produced a twenty-year cash flow statement with NPV and IRR values that indicate that the well is also profitable given these assumptions. Table 4.6 lists the results of the cash flow statement:

Table 4.6

Results from the cash flow statement with a shale gas well drilled in year zero and ten

\begin{tabular}{|l|l|}
\hline \multicolumn{2}{|c|}{$\begin{array}{c}\text { Cash flow statement assuming a new } \\
\text { shale gas well was drilled in year ten } \\
\text { summary data }\end{array}$} \\
\hline EUR & $8.26 \mathrm{Bcf}$ \\
\hline NPV & $\$ 2,154,848$ \\
\hline IRR & $21 \%$ \\
\hline
\end{tabular}

With two wells being drilled in the twenty-year time frame the most amount of gas was produced along with a net present value of the cash flow statement being larger than the other two cash flow statements that assumed there would be twenty years of production.

\subsection{Breakeven prices}

In addition to calculating the net present values and internal rates of return, the initial breakeven price of natural gas was able to be determined for each of the cash flow 
statements. The breakeven price of natural gas represents the price for natural gas that the producer requires in time 0 in order to achieve a minimum 10 percent return on investment. This value was calculated by determining what price of gas yielded a value of \$0 NPV using a 10 percent discount rate. The value calculated for the initial breakeven price of gas was assumed to increase by 2.1 percent per year, as did the initial price of gas used in the cash flow statements. By allowing the price to increase by 2.1 percent each year the breakeven price was more representative of the minimum price producers require before they begin drilling. Table 4.7 shows a summary of all of the breakeven prices found for each of the cash flow statements:

Table 4.7

Breakeven price results for all scenarios

\begin{tabular}{|l|l|}
\hline \multicolumn{2}{|c|}{ Summary of breakeven prices } \\
\hline Scenario: & Resulting initial breakeven price (per mcf): \\
\hline 10 years of production & $\$ 3.29$ \\
\hline 20 years of production & $\$ 2.94$ \\
\hline $\begin{array}{l}\text { 20 years of production including } \\
\text { workovers and re-stimulation }\end{array}$ & $\$ 3.27$ \\
\hline $\begin{array}{l}20 \text { years with assumption of wells } \\
\text { being drilled in year 0 and 10 }\end{array}$ & $\$ 3.09$ \\
\hline
\end{tabular}

All of the resulting breakeven price calculations produced values below the annual average wellhead price of gas in 2011 of $\$ 4.04$ per mcf of natural gas (Energy Information Administration 2011). Consequently, these results serve as another indication that the economics of shale gas production are currently favorable in the Marcellus Shale based on the assumptions and input values used in this analysis. By allowing the well to produce natural gas for twenty years under each of the assumptions 
listed produced breakeven prices that were all lower than the $\$ 3.29$ per mcf value found if the well only produced for ten-years. The lowest value of $\$ 2.94$ was a result of the twenty-year cash flow that assumed no workovers or re-stimulation and thus did not incur any significant costs in the later production years of the well. The impact of costs in the later years of production can be seen in the difference of only $\$ 0.02$ in breakeven prices between the ten-year cash flow and twenty-year cash flow that assumed workovers and re-stimulation.

\subsection{Breakeven costs of production}

Another important result that was calculated based on the data in the cash flow statements was the breakeven cost of production based on each of the different series of assumptions made. While the breakeven price of natural gas represented the price for gas that allowed the producer to achieve a 10 percent return on investment, the breakeven cost of gas shows how the per unit cost of production changes over time and as more natural gas is produced. As the quantity of natural gas produced increases, the cost decreases to produce each additional unit of gas. The breakeven cost is a before tax (and tax benefits) calculation that is representative of the cumulative costs of production divided by the cumulative natural gas produced at any point during the production life of the well.

As can be seen in Figures 4.9, 4.10, 4.11 and 4.12, the per-unit cost of production decreases as the cumulative amount of natural gas produced increases. All of the cash flow statements produced equivalent breakeven costs for the first ten years of production 
since the changes in assumptions regarding the time frame of production and additional production costs were made in year ten and the subsequent ten years were different for each cash flow statement. In each of the figures below, there are interruptions in decline of the breakeven costs as more natural gas is produced. The interruptions are a result of any additional costs that were incurred throughout the life of the shale gas well. The increase in breakeven costs seen in Figure 4.9 for example, is because of the additional costs associated with renewing the lease for an additional five years. Figures 4.11 and 4.12 experienced the biggest increase in breakeven costs in the later years of production because of the significant costs associated with performing workovers and re-stimulation (Figure 4.11) or drilling a new well (Figure 4.12). The combination of declines in production over the life of the shale gas well and additional costs associated with production result in Figures 4.9, 4.10, 4.11 and 4.12, showing the decrease in the breakeven costs becoming increasingly more gradual as more natural gas is produced.

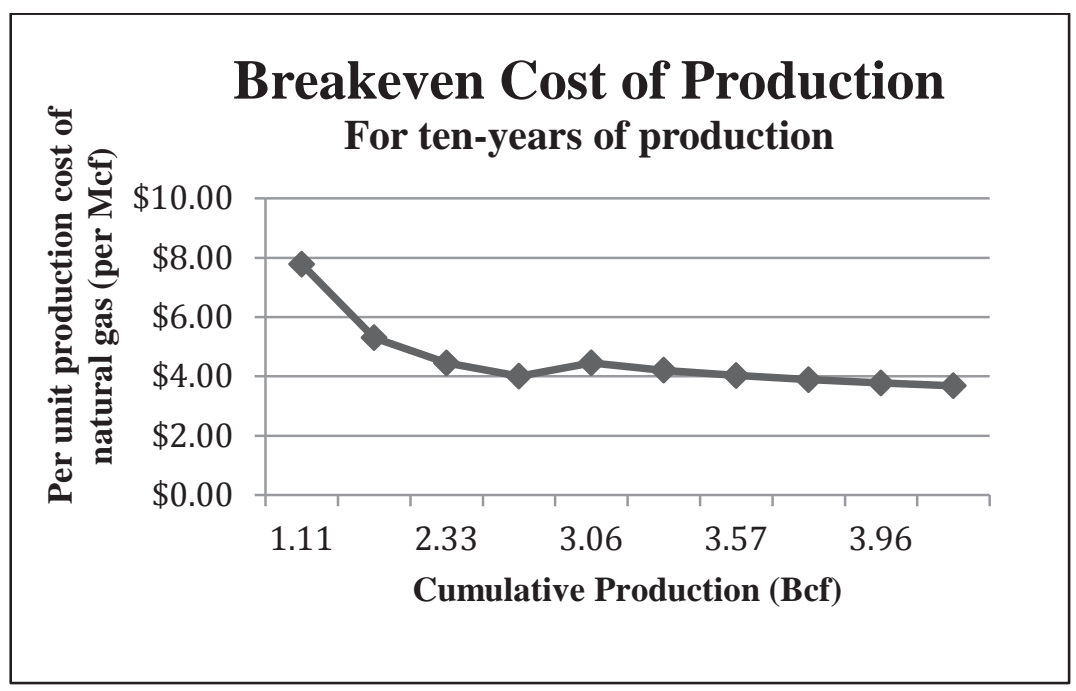

Figure 4.9 - Graph showing the change in the before tax breakeven cost of production as more natural gas is produced by a shale gas well under the assumption of ten years of production. 


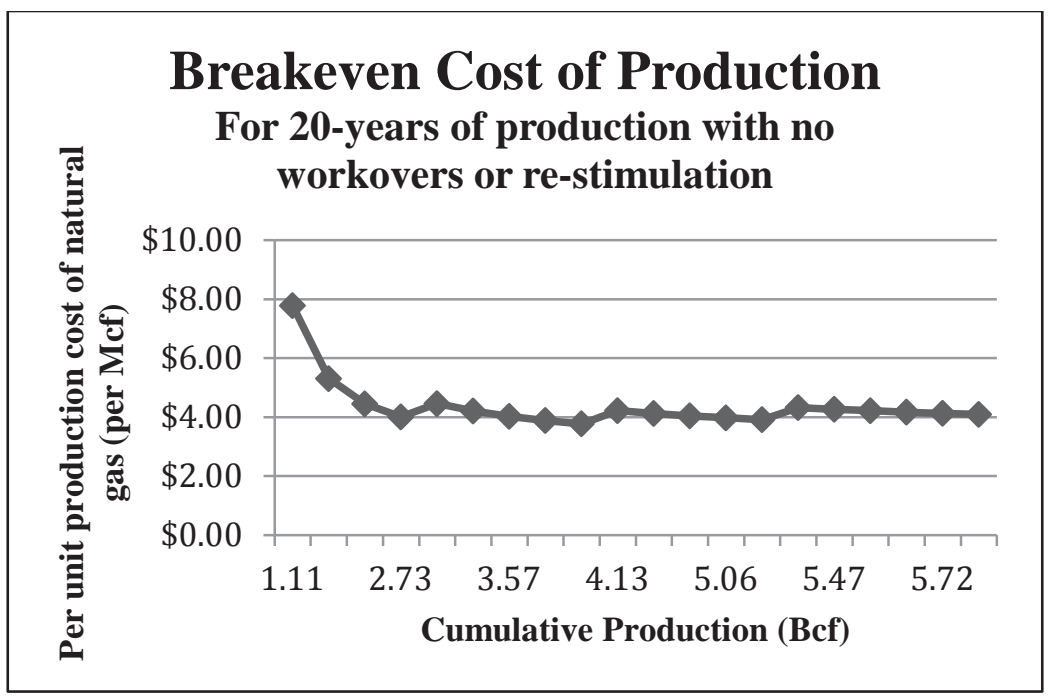

Figure 4.10 - Graph showing the change in the before tax breakeven cost of production as more natural gas is produced by a shale gas well that produces gas for twenty years.

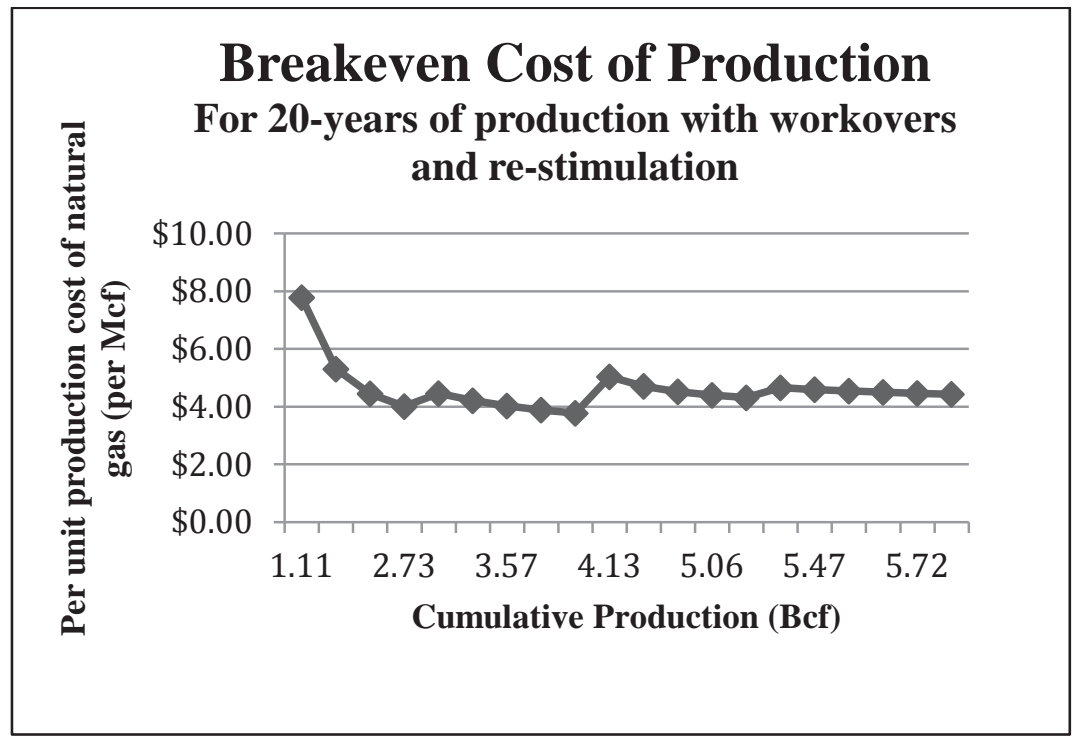

Figure 4.11 - Graph showing the change in before tax breakeven cost of production as the amount of natural gas produced increases by a shale gas well that produces gas for twenty years with the additional assumption workovers and restimulation efforts were completed in year ten. 


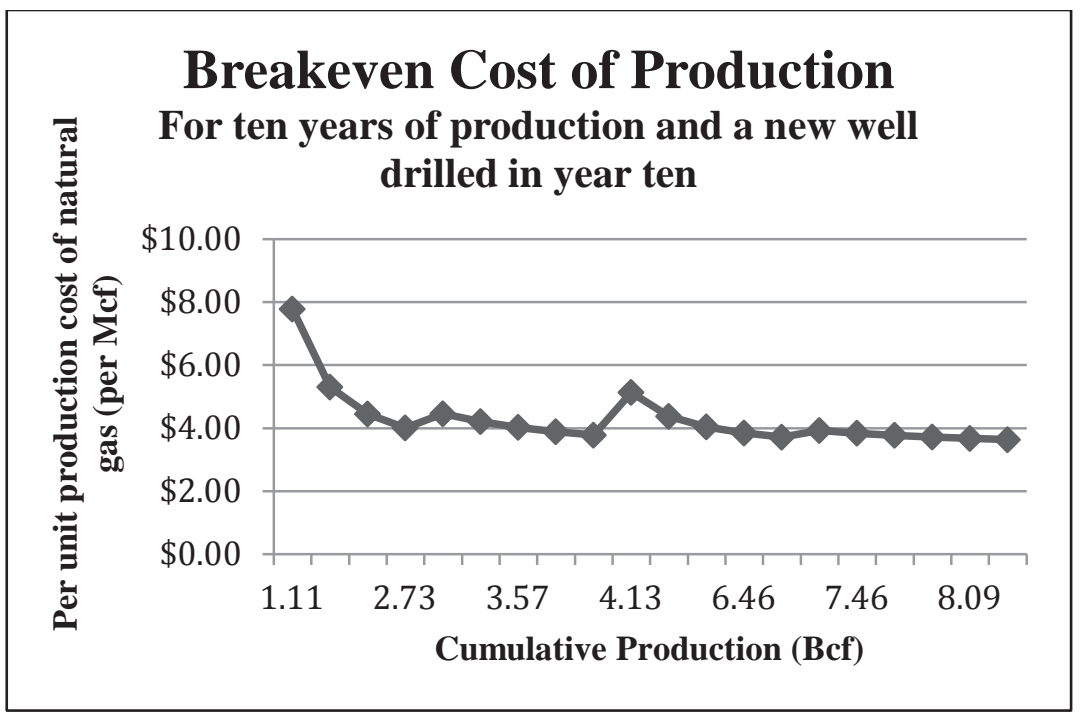

Figure 4.12 - Graph showing the change in overall before tax breakeven cost of production with the assumption that a shale gas well would be drilled in year 0 and another in year 10 with each well producing natural gas for ten years.

Tables 4.8 and 4.9 shown below include some of the specific breakeven costs

derived from the cash flow statements based on the amount of natural gas that was

produced. As a result of the first ten years of production being equivalent for each of the cash flow statements, the breakeven cost of production for the first four billion cubic feet of gas shown in Table 4.8 is equivalent as well.

Table 4.8

Breakeven costs of production based on varying amounts of natural gas production

\begin{tabular}{|l|l|l|l|l|}
\hline \multicolumn{5}{|c|}{ Summary of Breakeven Costs of Production } \\
\hline $\begin{array}{l}\text { Amount of Gas } \\
\text { Produced (Bcf) }\end{array}$ & 1 & 2 & 3 & 4 \\
\hline $\begin{array}{l}\text { Resulting breakeven } \\
\text { cost for all cash flows }\end{array}$ & $\$ 7.01$ & $\$ 5.01$ & $\$ 4.05$ & $\$ 3.76$ \\
\hline
\end{tabular}


Table 4.9 shows the different breakeven costs of production for the cash flow statements based on 5 billion cubic feet of production. The breakeven costs are higher than for $4 \mathrm{Bcf}$ of natural gas because of the additional costs associated with lease renewals, workovers and re-stimulation efforts or the costs associated with drilling a new well. Overall the shale gas well produced the lowest breakeven cost for production based on a production life of twenty-years with no workovers or re-stimulation activities done to the well.

Table 4.9

Breakeven cost of production based on five billion cubic feet of natural gas production

\begin{tabular}{|l|l|}
\hline \multicolumn{2}{|c|}{ Breakeven cost for 5 Bcf of natural gas } \\
\hline Cash flow: & Breakeven Cost: \\
\hline $\begin{array}{l}\text { 20-years of production with no } \\
\text { workovers or re-stimulation }\end{array}$ & $\$ 4.20$ \\
\hline $\begin{array}{l}\text { 20-years of production with } \\
\text { workovers and re-stimulation }\end{array}$ & $\$ 4.43$ \\
\hline $\begin{array}{l}\text { 20-years of production with a } \\
\text { new well drilled after 10-years }\end{array}$ & $\$ 4.53$ \\
\hline
\end{tabular}

\subsection{Comparison of results}

Each of the cash flow statements produced positive net present values, internal rates of return greater than the minimum acceptable rate of return of 10 percent and breakeven prices less than the annual average wellhead price of natural gas in 2011. The positive results however were different for each cash flow statement based on the assumptions made and consequently it is beneficial to see all of the results together for 
easier comparison. Table 4.10 below shows the results of each cash-flow statement that was constructed.

Table 4.10

Comparison of the results found from each of the cash flow statements

\begin{tabular}{|l|r|r|r|r|}
\hline \multicolumn{5}{|c|}{ Comparison of results } \\
\hline Cash flow statement: & EUR: & NPV: & IRR: & $\begin{array}{l}\text { Breakeven } \\
\text { Price: }\end{array}$ \\
\hline 10-year & 4.14 & $\$ 1,156,284$ & $19 \%$ & $\$ 3.29$ \\
\hline $\begin{array}{l}\text { 20-year no workovers or re- } \\
\text { stimulation }\end{array}$ & 5.24 & $\$ 1,884,464$ & $24 \%$ & $\$ 2.94$ \\
\hline $\begin{array}{l}\text { 20-year with workovers and } \\
\text { re-stimulation }\end{array}$ & 5.67 & $\$ 1,389,170$ & $21 \%$ & $\$ 3.27$ \\
\hline $\begin{array}{l}\text { 20-year with assumption of } \\
\text { new well drilled after ten years }\end{array}$ & 8.26 & $\$ 2,154,848$ & $21 \%$ & $\$ 3.09$ \\
\hline
\end{tabular}

Extending the life of the shale gas well for twenty years of production while not performing any workovers or re-stimulation is one of the best options for a producer.

The NPV, IRR and breakeven price of natural gas were the best under the assumption of no workovers or re-stimulation while maintaining twenty-years of production. The NPV and IRR values under those assumptions were $\$ 495,294$ and 3 percent greater respectively than the NPV and IRR values for the cash flow under the assumption that workovers and re-stimulation efforts were completed. Furthermore, by allowing the shale gas well to produce gas for twenty years, the producer gained an additional $\$ 728,180$ in net present value over the resulting NPV from the ten-year production time frame. The breakeven price resulting from the twenty-year cash flow that assumed no workovers or re-stimulation was also the lowest calculated at $\$ 2.94$ per mcf of natural gas. 
The highest net present value however of $\$ 2,154,848$ was achieved based on the assumption that the producer drilled a new shale gas well in year ten and the production and cost characteristics were assumed to be equivalent to those found in the first tenyears. Additionally, the second lowest breakeven price of natural gas of $\$ 3.09$ per mcf was found under these assumptions. These result coupled with an IRR of 21 percent indicate that the second best choice for a producer in the Marcellus Shale would be to drill a new shale gas well after ten-years.

While the NPV, IRR and breakeven price of gas were all in the range considered profitable for the shale gas well that assumed that workovers and re-stimulation efforts would be done to the well in ten, they were not great enough to conclude performing those activities is worth the capital requirements, given the assumptions and values used in this analysis. The cash flow statement that assumed a new shale gas well would be drilled in year ten produced an NPV $\$ 756,678$ greater than the $\$ 1,389,170$ achieved by the shale gas well that had workovers and re-stimulation efforts done to it. This result suggests that a producer would be better off spending the additional money to drill a new shale gas after ten-years as opposed to paying for workovers and re-stimulation of the well.

Regardless of whether the shale gas well produced natural gas for ten-years or twenty-years the results of the analysis still showed the well to be profitable. The favorable economic outcomes of the shale gas well are important due to the numerous adverse conditions currently facing the shale gas industry. Consequently, the profitability of the simulated shale gas well under the different assumptions made in this analysis results in a number of implications and conclusions that can be made for the economics 
of shale gas production in the Marcellus Shale. Chapter 5 will discuss those various implications and conclusions and relate them to some of the potential future factors that could significantly impact the shale gas industry. 


\section{Discussion of Results}

The rapid increase in shale gas production over the last decade, in places such as the Marcellus Shale, resulted in new trends and uncertainties in the natural gas industry, increasing concerns about the economics of shale gas production. The specific circumstances working against the economic viability of shale gas production include falling prices of natural gas, a state of domestic oversupply with minimal expected increases in U.S. natural gas demand in the future, high production costs and production decline issues associated with shale gas wells. Despite these concerns, results indicating profitability were obtained by creating a hypothetical shale gas well that used production and cost values observed from 2009 to 2011 by natural gas producers in the Marcellus Shale. The favorable economic results of shale gas production from the results of the analysis show that while many conditions related to shale gas economics are not positive, they are not bad enough for a typical shale gas well in the Marcellus Shale to be deemed unprofitable. Consequently, there are numerous implications and conclusions for shale gas production in the Marcellus Shale that can be made because of the positive results from the analysis. Many of these implications are related to potential future factors that may affect the economic outcomes found in the analysis. 


\subsection{Effects of production declines on the economic performance of the shale gas well}

The decline in natural gas production experienced throughout the life of a shale gas well had significant effects on the overall economics of the analysis. The declining rate of production resulted in a majority of the natural gas being produced early in the life of the well. For example, the analysis showed that if the shale gas well produced natural gas for twenty-years assuming no workovers or if it produced natural gas for twenty-

years with workovers, 50 percent of the total expected production would occur by the end of 44 months or 52 months of production, respectively. This leaves approximately, an additional 15 years worth of natural gas production, to produce the remaining 50 percent of natural gas that is expected to be produced. This means that the longer the shale gas well produces natural gas, the less the net impact of each additional unit of natural gas produced will have on the overall amount of natural gas produced.

The reason the decline in production has such a large impact on the economic outcome of a shale gas well is related to how the revenue from a natural gas well is calculated. The annual revenue that can be expected in a given year is a result of the amount of gas produced and sold in a given year multiplied by the price of natural gas received. Consequently, the majority of revenues that can be expected are obtained early in the life of the well with only minimal additional economic impact to the overall profitability the longer the well produces natural gas. This puts considerable emphasis on the initial production and cost characteristics of the shale gas well. By decreasing initial 
costs and working to increase initial production, a shale gas well can achieve greater profitability than by working to only achieve a longer production life.

Additionally, the importance of a majority of revenues being obtained by a shale gas well in the first several years of production also correlates to short-term natural gas price activity being more important to the overall economics of the shale gas well than long-term price expectations. Because the amount of natural gas produced by the shale gas well in the later years of production will be so much less than during the initial few years, the long-term price activity will not have as great an impact on the overall profitability of the well. Thus, if forecasts for natural gas prices for the next few years change from the expected 2.1 percent annual increase that was estimated by the EIA to expectations of a negative price trend, it may be beneficial for producers to try and shutin shale gas wells if they have the capability or delay drilling new shale gas wells until natural gas prices increase.

\subsection{Impact of increased production costs on overall profitability}

As was discussed in chapter 2, the costs of shale gas production have been increasing for more than a decade because of the increase in demand and resulting shortage of drill rigs, personnel, and drilling supplies along with increases in the cost of leases. Despite the high costs of production that were factored into the analysis, the results showed that a typical shale gas well in the Marcellus Shale is still profitable. Table 5.1 shows that by increasing the production costs including lease bonus rates, royalty rates and lease operating costs for the cash flow statement that assumed twenty 
years of production with no workovers or re-stimulation that a shale gas well still can maintain profitability.

Table 5.1

Change to NPV results if production costs are increased while keeping other assumptions the same

\begin{tabular}{|c|c|}
\hline $\begin{array}{c}\text { Change to NPV results of the twenty year production scenario when } \\
\text { production costs increase annually }\end{array}$ \\
\hline \begin{tabular}{c} 
Percentage change in production costs \\
\hline $5 \%$
\end{tabular} \\
\hline $10 \%$ & $\$ 1,370,394$ \\
\hline $15 \%$ & $\$ 356,323$ \\
\hline
\end{tabular}

The degree of profitability was affected, however, when production costs related to workovers and re-stimulation activities were accounted for in the analysis. While the results were considered profitable, they were the least profitable of any cash flow scenario considered. Significant costs such as those incurred through workovers and restimulation efforts are hard to recoup in the later years of production because the majority of production, and therefore revenues, were received early in the production life of the well. As a result of the declines in production any significant production cost during the later years of production must be offset with large enough increases in production to not only pay for the expenses but also improve the economics of the situation. This includes costs such as workovers and re-stimulation activities or increases in lease bonus payments.

Furthermore, based on the assumptions for workovers and re-stimulation efforts of 60 percent of the original drilling and completion costs and production increases to 40 percent of the original production rate, the results were not great enough to justify 
spending the money. This is in comparison to the results of the twenty year scenario with no workovers or re-stimulation, which yielded more impressive results for the NPV, IRR and breakeven price. Specifically, the NPV and IRR were \$495,294 and 3\% greater respectively and the breakeven price was $\$ 0.33$ lower than when workovers and restimulation efforts were included. While the capital required to drill a second shale gas well in year ten is greater than the capital requirements for workovers and re-stimulation efforts, it results in the overall NPV increasing by $\$ 765,678$ and the breakeven price decreasing by $\$ 0.18$. The results from the addition of workovers and re-stimulation activities on the overall economic outcome of a shale gas well indicate that production costs should be limited as much as possible or the production increases from those costs must be significant in order to achieve the most favorable economic results.

Additionally, there is a possibility that costs associated with shale gas production may increase in the future as a result of regulations related to hydraulic fracturing that may be imposed to decrease the likelihood of environmental problems. There have been allegations that hydraulic fracturing may lead to groundwater contamination issues and other environmental problems because of the potential for methane or fracking fluid to seep through the artificial fractures created below ground, and contaminate subsurface aquifers (Environmental Protection Agency 2012). To investigate the allegations and potential for environmental problems resulting from fracking, the EPA has launched a detailed investigation. The results of the EPA investigation are supposed to be released sometime in late 2012 (Environmental Protection Agency 2012). Depending on the findings and recommendations of the study there is a chance that increased regulations will be imposed on fracking. If legislation increases regulations, there would be 
additional costs associated with more permitting, new fracking related equipment, employee training and other expenses necessary to comply with the regulations (Environmental Protection Agency 2012). Estimates of the cost increase as a result of such regulations is about $\$ 300,000$ to $\$ 900,000$ per well (Jacoby, O'Sullivan and Paltsev 2012). This amount of cost increase would negatively affect the overall profitability of shale gas production in the Marcellus Shale but would not yield a great enough impact to deem a shale gas well uneconomical.

As of 2011, there has not been any conclusive evidence that proves a direct correlation between fracking and groundwater contamination and, as a result there only exists a possibility that new regulations will be passed in the near future. The impact of increased regulations related to fracking and environmental issues on the overall economics of the shale gas well were not factored into the analysis because of the uncertainty of if and when those regulations will be passed and imposed.

\subsection{Oversupply and slow growth in demand could cause trouble in the future}

The oversupply situation and expected modest increases in natural gas demand in the next twenty years will be one of the greatest issues that must be dealt with to help improve the overall outlook of shale gas economics. Without any significant increases in demand or a solution to deal with the oversupply of natural gas, the price of gas will not experience any notable recovery, and may not be able to increase by the expected annual increase of 2.1 percent per year. Natural gas demand and oversupply issues are relevant 
to the results of the analysis because of the assumption that all of the natural gas that was produced in a given year would be sold for that year's given annual average wellhead price. As a result of expected stagnant demand for natural gas and an already existent oversupply issue in the U.S., it may become increasingly difficult to sell all the gas produced each year at a favorable price. In addition, more gas production without increases in demand or use will result in further price declines. If there is an inability to sell all of the gas produced each year and the price of natural gas declines, the annual revenue received will decrease and consequently affect the overall economics of the shale gas well. To help illustrate the impact of future changes in price, Table 5.2 shows the NPV results if the price of natural gas were to remain constant at the 2011 level or decline by varying percentage rates. The NPV results were obtained by changing the natural gas price for the cash flow statement that assumed twenty years of production with no workovers or re-stimulation efforts.

Table 5.2

Change in NPV results when price of natural gas remains constant or declines over the life of a shale gas well while keeping other assumptions the same.

\begin{tabular}{|l|l|}
\hline \multicolumn{2}{|c|}{$\begin{array}{c}\text { Change in NPV results when price of natural gas varies from an } \\
\text { initial starting point of } \mathbf{\$ 4 . 0 4} \text { per mcf }\end{array}$} \\
\hline Annual change in natural gas price & NPV \\
\hline $0 \%$ & $\$ 1,443,142$ \\
\hline$-5 \%$ & $\$ 614,451$ \\
\hline$-10 \%$ & $\$ 4,214$ \\
\hline
\end{tabular}

As long as a shale gas well has production and cost values similar to those used in the analysis, the well can tolerate a considerable decline in price while maintaining 
profitability. The degree of profitability however decreases significantly as the price of natural gas declines.

One way to deal with the uncertainty of demand and potential problems associated with selling all of the gas produced in a given year for a favorable price is to try and maximize the overall profitability of a shale gas well with the lowest amount of natural gas required to be sold. This concept can be illustrated by examining the results of the cash flow statements for twenty years of production with no workovers and the cash flow statement that assumed a new shale gas well would be drilled in year ten.

Table 5.3

Comparison of results from the cash flow statement that assumed twenty years of production with no workovers and the cash flow statement that assumed a new shale gas well would be drilled in year ten

\begin{tabular}{|l|l|l|}
\hline \multicolumn{3}{|c|}{$\begin{array}{c}\text { Comparison of results for shale gas well under assumption of 20 years of } \\
\text { production with no workovers vs. a new shale gas well being drilled in year 10 }\end{array}$} \\
\hline Cash flow statement & NPV & $\begin{array}{l}\text { EUR (Bcf of natural } \\
\text { gas) }\end{array}$ \\
\hline $\begin{array}{l}\text { 20 years of production } \\
\text { with no workovers }\end{array}$ & $\$ 1,884,464$ & 5.24 \\
\hline $\begin{array}{l}\text { New well drilled after ten } \\
\text { years }\end{array}$ & $\$ 2,154,848$ & 8.26 \\
\hline
\end{tabular}

While drilling a new shale gas well after ten years produced a greater NPV, it also requires that more natural gas must be sold throughout the life of the well. The cash flow statement under the assumption of twenty years of production with no workovers yielded a high NPV, IRR and lower breakeven price than the other than the other scenarios except drilling a new well along with producing 3.02 Bcf less of natural gas. 
Furthermore, the demand and oversupply issues associated with natural gas may not be as bad for natural gas producers in the Marcellus Shale. The geographic location of the Marcellus Shale may give shale gas wells in that region an advantage as compared to wells in other shale deposits because the Marcellus is close to northeast population centers. As a result, there are lower transportation costs associated with getting the natural gas from the wells to consumers. The lower transportation costs would help result in lower overall costs of natural gas for consumers and may help increase the demand for natural gas from the Marcellus Shale. This would help keep the economics of shale gas production in the Marcellus Shale more favorable than gas produced from other deposits.

Additionally, there are at least three possible ways that the domestic demand for natural gas may increase in the next twenty years. These two methods include the passing of climate change legislation that requires the use of low-carbon emitting energy sources and the potential for the U.S. to begin exporting natural gas. There is uncertainty however as to whether either of these events will occur and as a result of this, the economic impacts of these events were not factored into the analysis.

The first way domestic natural gas demand could increase would be a result of legislation being passed that aims to decrease carbon emissions (Naturalgas.org 2011). Shale gas would be affected by such legislation because of the cleaner burning qualities of natural gas compared to coal or oil (Energy Information Administration 2009). Natural gas would see increases in demand as companies and consumer work to decrease their carbon emissions in an economically viable way (Naturalgas.org 2011). Moreover, natural gas from shale deposits is plentiful in the U.S., economical to produce and 
affordable to consumers. This makes shale gas more attractive than some other energy resources such as solar power.

Demand for natural gas could increase as well without the help of legislation. One way in particular for how this is possible is through the shift of electricity generation from coal to natural gas. Electricity generated by natural gas is increasingly favorable because of the efficiency of natural gas generators, the lower price of natural gas, lower costs associated with building natural gas fired power plants as compared to nuclear or renewable plants, and because the public and various political programs have been advocating for cleaner energy sources (Energy Information Administration 2012b). Because of the benefits of electricity generated by natural gas the E.I.A. expects that over the next two decades natural gas fired plants will account for approximately 46 percent of the new electricity capacity additions whereas coal plants will only account for approximately 12 percent of new additions (Energy Information Administration, 2011). If the price of natural gas stays low the economics of using gas for electricity generation will become more advantageous and may motivate a greater number of new natural gas fired plants to be built or a faster transition from coal to natural gas.

A third way domestic natural gas demand could increase and the current oversupply situation could be dealt with is through the ability to export natural gas from the U.S. There are currently no capabilities in the U.S. to export natural gas and consequently new facilities will be required. Exporting natural gas is difficult because of the technical issues related to transporting natural gas and financial requirements necessary to fund the building of the exporting infrastructure. Natural gas is difficult to export because it must first be super-cooled to a liquid form in order to be put into 
specialized natural gas tankers. The process, equipment and infrastructure associated with natural gas liquefaction is expensive and will require about $\$ 5$ billion in capital to build the first export facility (Meyer 2011).

One company that is actively working towards becoming the first U.S. natural gas exporter is Cheniere Energy. They have acquired permits and obtained authorization to begin construction on a LNG export facility in Louisiana (Meyer 2011). As long as Cheniere can secure the necessary financing required to build the export facility, they plan on having the capability to begin to export natural gas by 2015 (Meyer 2011). Additionally, it would be economically advantageous to export natural gas to places such as Europe or China where the current prices of natural gas are two to three times greater than the U.S. price of gas as of 2011 (Editorial Board 2012). This arbitrage opportunity available from exporting natural gas may not only justify the costs of natural gas liquefaction but would also allow for a profitable venture (Editorial Board 2012).

\subsection{The importance of the price of natural gas on overall profitability}

While producers can forecast what to expect with costs and production performance related to a shale gas well, it is more difficult to forecast what to expect in regards to price activity (Energy Information Administration 2002). This is problematic because the price of natural gas along with the amount of natural gas that can be produced are the two primary determinants of the revenue received from a shale gas well. In section 5.1 it was discussed that the majority of revenues occurs early in the life of the 
well. Related to that is the positive correlation between prices and revenues: the greater the price of natural gas, the larger the revenues.

The price of natural gas is determined by supply and demand factors with the biggest change in price occurring after 2008 when the price of natural gas fell as a result of the financial crisis and oversupply of natural gas (Energy Information Administration 2002) (Energy Information Administration 2012a). The resulting low price then caused problems with shale gas economics because of the low revenues from shale gas wells. If demand does not increase and the oversupply problem of natural gas is not dealt with, the price of gas could potentially decrease in the next several years. This would cause a larger negative impact on the revenues of shale gas wells than what was experienced after 2008 because natural gas prices are already at low levels.

To help protect against price declines, shale gas wells should aim to achieve the lowest breakeven price possible. A lower breakeven price of natural gas equates to a lower price of natural gas that can be tolerated while still maintaining profitability. Additionally, if the price of natural gas happens to increase, profitability of the shale gas well will be increased as a result of the low costs and doing what is necessary to achieve the lowest breakeven price possible. One method that was shown in the analysis to help decrease the breakeven price was to increase the time frame of production of the shale gas well. This was shown by the results of the twenty-year cash flow statement with no workovers or re-stimulation that produced a breakeven price of $\$ 2.94$ per Mcf of natural gas, a $\$ 1,884,464 \mathrm{NPV}$, and a 24 percent IRR. This breakeven price was $\$ 1.10$ per mcf of natural gas lower than the average annual wellhead price of natural gas in 2011 of \$4.04 per mcf. 
Along with increasing the time frame of production, costs must be limited and additional expenses such as workovers should not be undertaken unless the increase in production is great enough to offset the costs while still lowering the breakeven price. The results when workovers and re-stimulation efforts were included in the analysis produced a breakeven price of gas that was only $\$ 0.02$ per mcf lower than compared to the ten-year cash flow statement. This breakeven price was also $\$ 0.33$ per mcf greater than the breakeven found for the cash flow that assumed twenty years of production with no workovers.

\subsection{Methods used to increase economic favorability of shale gas operations}

Natural gas producers can use various methods to help protect against price uncertainty and cost variability. The expected economic performance of a shale gas well can be improved by decreasing the potential negative impact of various future events such as price declines or cost increases. Two important methods used to help improve the economics of shale gas production and protect against the risks of price volatility include transitioning some production to "liquids-rich" gas plays and the use of derivatives. The simulated Marcellus Shale well used in this analysis did not include these two methods because the goal was to show the economic viability of a typical shale gas well without financial engineering.

First, the analysis assumed that the simulated shale gas well would be limited to dry-gas production to allow for a more pure gas analysis and to be representative of many 
of the shale gas wells drilled in the Marcellus Shale. There are, however, locations to drill in the Marcellus Shale that contain natural gas liquids. Wells that produce NGL's along with methane are known as wet-gas wells. The production of wet-gas becomes increasingly favorable in times of low natural gas prices but when the price of oil stays high. Natural gas liquids such as butane, propane and ethane can be sold for a premium over methane because NGL's more closely follow the price of crude oil and not natural gas (Chesapeake Energy Corporation 2011). As a result of the increased profitability of the NGL's in times of low natural gas prices but high oil prices, the breakeven price of shale gas wells can decrease and become more profitable.

A second method used to improve the profitability of shale gas wells is through the use of derivative contracts. The use of derivatives can help lower the risk of price volatility and can possibly help increase profits if used successfully (Energy Information Administration 2002). One example of how derivatives are used by natural gas producers is in the form of futures contracts, which allow a natural gas producer the opportunity to lock in the price they will receive for the gas they will produce in the future. The benefit of entering into a futures contract would be to avoid the negative impact of a decrease in the price of natural gas. Conversely, by entering into futures contracts the producer would also be unable to benefit from a price increase, consequently it is often not in the best interest to sell all of the gas with futures contracts (Energy Information Administration 2002).

Derivatives can also be used to help increase the overall realized price of gas based on speculative trades and other more complicated trading techniques (Energy Information Administration 2002). This practice can be especially useful in times when 
the market price of natural gas is slightly below the breakeven price of natural gas. By using derivative contracts and speculative trades a natural gas producer can attempt to increase for price of natural gas they actually receive to be more than the breakeven price. Price increases resulting from derivatives can only work up to a certain point because for every trader who believes the price of natural gas will increase there must be another trader who believes the price will decrease. Therefore, it would be unrealistic to expect to be able to consistently increase the price received after derivatives to more than a few dollars at the most.

Futures contracts and other derivatives can be financially beneficial to natural gas producers but positive performance is not guaranteed. Therefore, the results of positive well profitability based on the annual average wellhead price of natural gas was important as it represented the price of gas many producers would factor into their calculations to see if their activities would be profitable based on current market conditions for natural gas. Because the outcomes of utilizing derivatives is not certain, companies must make sure their natural gas operations are profitable based on the price of natural gas they can most likely achieve (Energy Information Administration 2002).

\subsection{Importance of the allowable tax deductions used in the analysis}

The favorable economic outcomes that were obtained from the cash flow statements were not solely a result of the production and cost characteristics used in the shale gas well analysis. In addition to the production and cost characteristics, overall

profitability was possible because of the use of allowable tax benefits available to the oil 
and gas industry. The ability to account for depletion and allow for the deduction of expenses such as intangible drilling costs helped decrease the negative impacts of the millions of dollars required to drill the well, acquire the lease rights and pay for lease operating expenses. Furthermore, the allowable tax benefits help to promote shale gas production despite the negative conditions of the shale gas industry such as low natural gas prices and high production costs.

In addition to allowable tax deductions, another tax-related incentive was the absence of a severance tax. As of 2011, Pennsylvania does not have a severance tax, which acts as an incentive for shale gas production because many other states such as Arkansas, Michigan, Oklahoma and Texas do impose a severance tax on natural gas production making overall costs to produce gas in those states greater than in Pennsylvania (Brock 2012). A severance tax is a tax on the amount of natural gas produced and usually represents a rate of about 5 to 8 percent of the natural gas produced by a well (Brock 2012). While the addition of a severance tax would increase state revenue for Pennsylvania, it would also jeopardize some of the incentive for natural gas producers to drill shale gas wells in Pennsylvania. However, if the Pennsylvania State Government does decide to impose a severance tax, the 5 to 8 percent of production it would represent would not cause a great enough negative impact to significantly affect the overall economics of wells in the Marcellus Shale. This can be shown by implementing a severance tax that represents 8 percent of the value of natural gas produced each year on the cash flow statement that assumed twenty years of production with no workovers or re-stimulation. The NPV after the addition of a severance tax is 
$\$ 644,207$ lower than if the tax were not present. The overall NPV however is still over $\$ 1$ million at a value of $\$ 1,240,257$.

The possibility also exists that the federal government could eventually disallow some of the tax benefits available to the oil and gas industry (Schoen 2011). Critics and some politicians argue that the use of tax benefits only helps companies earn excessive profits while not paying their fair share of taxes (Schoen 2011). There is no guarantee that the allowable tax deductions will be allowed forever and as a result shale gas wells should not rely solely on tax deductions for economic viability. The magnitude of the results calculated from the analysis implies that if some of the tax deductions were not allowed shale gas wells would still be profitable. To illustrate this scenario, the depreciation of tangible costs and the ability to separate tangible and intangible drilling costs were removed from the cash flow statement that assumed twenty years of production with no workovers or re-stimulation efforts. After the removal of the two tax benefits the cash flow was still profitable with an NPV of $\$ 187,471$. However, by not allowing the depreciation of tangible costs and differentiation of tangible versus intangible drilling costs the NPV decreased by $\$ 1,696,993$. If prices decline or production costs increase along with the removal of allowable tax deductions, the overall profitability of the well would likely disappear.

\subsection{Tolerance for future volatility while maintaining profitability}

All of the results from the cash flow statements under the various scenarios were profitable. Given the increase in production costs and low natural gas prices that were 
factored into the cash flow statements, it could be expected that the values should have been perhaps only marginally profitable. This was not the case, however, because the NPV, IRR and breakeven prices of the shale gas well under different assumptions were all significantly greater than the thresholds that are needed for profitability. Consequently, the magnitude of these results implies that a typical Marcellus Shale well that has input values similar to what were used in the analysis could tolerate some volatility and still remain profitable. Volatility that causes higher prices and lower costs than assumed in the analysis would yield greater profitability and values for prices and costs that are worse than what were assumed in the analysis would decrease profitability. The values and the assumed trends used in the analysis represent a likely scenario for what may happen within the shale gas industry in the Marcellus Shale but uncertainty regarding the future of shale gas production exists. The preceding sections of this chapter mentioned some of various reasons for the uncertainty related to natural gas prices, cost components and demand for natural gas.

The magnitude of positive economic results however, shown by the NPV, IRR and breakeven prices derived from the cash flow statements imply that producers would be likely to maintain profitability even if future conditions of production and costs were worse than what was assumed in the analysis. Table 5.2 in section 5.3 showed that even if natural gas prices decline by 5 to 10 percent over the next two decades that the net present value of a shale gas well would still be profitable. Additional results helping to show that profitability can be maintained despite negative price conditions are shown in Table 5.4. This table shows the results if the price of natural gas remained constant at the 2011 level of $\$ 4.04$ per mcf of natural gas. 
Table 5.4

Results when the price of natural gas is kept constant in the cash flow statements

\begin{tabular}{|l|l|l|l|}
\hline \multicolumn{5}{|c|}{$\begin{array}{l}\text { Results if Price of Natural Gas is Kept Constant Throughout } \\
\text { Production Life of Shale Gas Well }\end{array}$} \\
\hline Scenario & NPV & IRR & $\begin{array}{l}\text { Breakeven } \\
\text { price }\end{array}$ \\
\hline 10 years of production & $\$ 877,809$ & $17 \%$ & $\$ 3.45$ \\
\hline 20 years of production & $\$ 1,443,142$ & $22 \%$ & $\$ 3.14$ \\
\hline $\begin{array}{l}\text { 20 years of production including } \\
\text { workovers and re-stimulation efforts }\end{array}$ & $\$ 859,867$ & $19 \%$ & $\$ 3.53$ \\
\hline $\begin{array}{l}20 \text { years with wells being drilling in } \\
\text { years 0 and 10 }\end{array}$ & $\$ 1,216,243$ & $17 \%$ & $\$ 3.45$ \\
\hline
\end{tabular}

Moreover, the breakeven prices that were found for each of the cash flow statements represent the constant price of natural gas needed in order to achieve a 10 percent return from the well. These values coupled with the results in Table 5.2 show that the shale gas well would be profitable even with significant declines in natural gas prices. In addition to being able to maintain profitability if natural gas prices decline, a shale gas well with similar production values could also withstand increases in production costs, as shown in Table 5.1, and still be profitable. If, however, production costs increase and prices decrease then the shale gas well will not be able to tolerate as severe of price declines. Table 5.5 shows the effect of annual percent changes in both natural gas prices and production costs including lease bonus rates, royalty rates and lease operating costs. The changes in prices and costs have been applied to the twenty year cash flow statement that did not assume workovers and re-stimulation efforts would be completed. 
Table 5.5

Change in NPV results if natural gas prices decline and production costs increase

\begin{tabular}{|c|c|c|}
\hline \multicolumn{3}{|c|}{$\begin{array}{c}\text { Impact of changes in natural gas prices and production costs on the NPV of } \\
\text { the twenty years of production scenario }\end{array}$} \\
\hline $\begin{array}{c}\text { Annual percent change } \\
\text { in natural gas prices }\end{array}$ & $\begin{array}{c}\text { Annual percent change in } \\
\text { production costs }\end{array}$ & NPV \\
\hline $0 \%$ & $0 \%$ & $\$ 1,884,464$ \\
\hline$-2.5 \%$ & $2.5 \%$ & $\$ 764,828$ \\
\hline$-5 \%$ & $5 \%$ & $\$ 176,888$ \\
\hline$-7.5 \%$ & $7.5 \%$ & $-\$ 339,155$ \\
\hline$-10 \%$ & $10 \%$ & $-\$ 797,391$ \\
\hline
\end{tabular}

When natural gas prices and production costs were changed to assume movement in a negative direction, it had the effect of decreasing the amount of change either variable could tolerate while maintaining overall profitability. The ability however, to accept some future volatility of production and cost variables helps to show that shale gas production in the Marcellus Shale will continue to occur and even likely increase in the future.

\subsection{Overall implications}

The favorable results produced from the analysis imply that shale gas production including the drilling of new wells will continue in the Marcellus Shale. And while prices and conditions related to shale gas production are already bad, the results from the analysis show that profitability can still be maintained even if the price of natural gas continues to fall. Furthermore, if prices, costs and conditions overall deteriorate more severely there are additional methods that can be used to help improve the overall 
economics of shale gas production and decrease some of the future risks. These methods include the use of derivatives and transitioning to drill more wet-gas wells.

In addition, to future fluctuations of natural gas prices and production costs there are other future factors that could also occur and would impact the economic viability of shale gas production. These future factors include events such as increased regulations as a result of the EPA finding a link between hydraulic fracturing and groundwater contamination, the addition of a severance tax in Pennsylvania, the discontinuance of the allowable tax deductions available to the oil and gas industry, legislation requiring increased use of low-carbon emitting energy sources and the ability to start exporting natural gas from the U.S. Each of these future factors would have a different degree of impact on the economics of shale gas production in addition to either helping or hurting the industry as a whole. Given the uncertainty of some of the future events related to shale gas production, it is important that the results show shale gas production in the Marcellus Shale to be profitable given the conditions from 2009 to 2011. 


\section{Conclusion}

As a result of using hydraulic fracturing and horizontal drilling, the U.S. has been able to economically and technologically develop several decades' worth of natural gas from shale deposits such as the Marcellus Shale. However, shale gas economics has raised considerable concern because of the additional costs associated with the use of hydraulic fracturing and horizontal drilling along with the adverse economic circumstances of the natural gas industry. When natural gas prices were near $\$ 10.00$ per mcf of natural gas in the years preceding 2008, there was a rapid increase in shale production that resulted in many unfavorable trends and circumstances for the natural gas industry. Such as declines in the rate of production throughout the life of the well, falling prices of natural gas, oversupply issues with slow expected growth for U.S. natural gas demand, and a decade of rising production costs. Despite these conditions, the analysis that was completed based on production and cost variables representative of those obtained by shale gas producers from 2009 to 2011 showed that a shale gas well in the Marcellus Shale is profitable. This profitability indicates that the number of shale gas wells drilled and the amount of natural gas produced in the Marcellus region will continue to increase.

The potential for numerous economic, environmental and political benefits exists through the increase of U.S. natural gas production. Some of the economic benefits associated with continued shale gas production from the Marcellus Shale will include increased profits for landowners, natural gas companies, local, state and federal governments along with investors. Additionally, the success of shale gas operations in 
the Marcellus Shale will help lead to increased employment for individuals working in the shale gas industry. Furthermore, increased natural gas production will be environmentally favorable because natural gas burns cleaner than coal or oil. As a result, natural gas will serve as an energy resource helping to bridge the gap between fossil fuels and cleaner energy solutions. The positive benefits related to jobs, economic growth and environmentally positive attributes of natural gas help make the increase in domestic natural gas both publically and politically popular.

But if natural gas production from the Marcellus Shale increases, it must proceed in a cautious manner. This is to avoid having the conditions of the shale industry further deteriorating and consequently causing additional concerns for the economics of shale gas production. The results of the analysis indicate that a shale gas well could remain profitable even with natural gas price and production cost volatility. Furthermore, through the use of derivatives and transitioning to more wet-gas wells, natural gas producers can help limit their risk and exposure to the possibility of negative market circumstances.

The long-term economic success however, of shale gas production in the Marcellus Shale, lies in the ability for domestic natural gas demand to increase. This is vital because the success in shale gas production over the last decade has left the U.S. in a state of oversupply. If this situation does not improve it could have detrimental effects on the price of natural gas as the demand for natural gas will continue to be unable to keep up with supply additions. Increasing the demand for natural gas will cause the prices to increase, which will allow shale gas producers to be able to sell the gas they produce for high prices, helping them earn larger profits. 
There are at least three methods that could help increase domestic natural gas demand and include the passing of legislation requiring the use of low-carbon energy sources, the increase in transition from coal to natural gas for electricity generation and the ability to export natural gas from the U.S. While these three methods would help increase demand, there is no guarantee they will come to fruition and consequently shale gas wells should make every effort to increase profitability while decreasing the breakeven price. This concept was best illustrated in the analysis by assuming twenty years of production with no workovers or re-stimulation efforts performed on the well that shows a breakeven price of $\$ 2.94$ per mcf in 2011.

Overall, while there are many concerns regarding shale gas economics and the possibility for certain circumstances to change in the future, the prices, costs and production performance data as of 2011 show that shale gas production in the Marcellus Shale is profitable. The current profitability of shale gas production coupled with the prospects of future actions to help to increase the demand for natural gas will result in natural gas production from places like the Marcellus Shale being economically viable for years to come. 


\section{Reference List}

Arthur J, Bohm B, Layne M. Considerations for development of marcellus shale gas, World Oil 2009; 230 (7): 65-69.

Baylor B. Marcellus Shale Decline Analysis. Paul Fulton Scholarship Paper, Marietta College [Internet]. 2010 [cited 2011 Oct. 14];15. Available from:

http://www.sooga.org/studies/Marcellus\%20Shale\%20Decline\%20Analysis\%20$\% 202010 \% 20-\% 20$ Brandon\%20Baylor.pdf

Brock R. Beebe Unsure About Severance Tax Support. [Internet] The City Wire. 2012 Jan. 25 [cited 2012 Jan. 25];2. Available from: http://www.thecitywire.com/node/20058

Brooks G. Musings: Marcellus Shale. Rigzone [Internet]. 2010 Sept. 28 [cited 2011 July 25];6. Available from: http://www.rigzone.com/news/article.asp?a_id=99414

Cabot Oil and Gas Corporation. Cabot Oil and Gas Corp, (COG) Form 10-k, Annual report pursuant to section 13 and 15(d), Filed on 02/28/2011, Filed Period 12/31/2010. Bloomberg Businessweek [Internet]. 2011 Feb. 28 [cited 2011 Nov. 10];123. Available from: http://investing.businessweek.com/research/stocks/financials/secfilings.asp?ticker=COG: US

Chesapeake Energy Corporation. Chesapeake Energy Corp, (CHK) Form 10-k, Annual report pursuant to section 13 and 15(d), Filed on 03/01/2011, Filed period 12/31/2010. Bloomberg Businessweek [Internet]. 2011 Mar. 1 [cited 2011 Oct. 10];148. Available from: http://investing.businessweek.com/research/stocks/financials/secfilings.asp?ticker=CHK: US

Considine T J. The Economic Impacts of the Marcellus Shale: Implications for New York, Pennsylvania, and West Virginia. American Petroleum Institute [Internet]. 2010 July 14 [cited 2011 Oct. 10];44. Available from: http://www.anga.us/media/44750/api\%20economic\%20impacts\%20marcellus\%20shale.p df

Cox C. The Marcellus and Utica Shale Natural Gas Play - What are the Issues? [Internet]. Plain City (OH): Cox-Colvin Associates Inc. - Environmental Services; 2012. [cited 2012 Jan. 15]. Available from: http://www.coxcolvin.com/Marcellus_Shale_Issues.php. 
Department of Environmental Protection. Guidelines for Submitting Oil and Gas Well Bonds [Internet]. Harrisburg (PA): Department of Environmental Protection; 2009 Dec. 2. [cited 2012 Jan. 14]. Available from:

http://www.elibrary.dep.state.pa.us/dsweb/Get/Document-77999/550-2501-101.pdf

Department of Environmental Protection. Marcellus Shale Permit Application Fees [Internet]. Harrisburg (PA): Department of Environmental Protection; 2011 May. [cited 2012 Jan. 14]. Available from: http://www.elibrary.dep.state.pa.us/dsweb/Get/Document84138/5500-FS-DEP4239.pdf

Dizard J. The Sleight of Hand Over Shale Gas Costs. The Financial Times [Internet]. 2010 Mar. 21 [cited 2011 Sept. 20];3. Available from: http://www.ft.com/intl/cms/s/0/6254ec9c-33f1-11df-8ebf00144feabdc0.html\#axzz1rkyH4mfq

Editorial Board. Boosting the Economy Through Natural Gas Exports. The Washington Post [Internet]. 2012 Mar. 14 [cited 2012 Mar. 15];2. Available from: http://www.washingtonpost.com/opinions/natural-gas-exports-offer-much-to-the-useconomy/2012/03/13/gIQA4WibCS_story.html

Energy Information Administration (US). Derivatives and Risk Management in the Petroleum, Natural Gas and Electricity Industries [Internet]. Washington D.C.: Deparment of Energy, Energy Information Administration. 2002 Oct. [cited 2011 Dec. 10]. Available from: http://www.eia.gov/oiaf/servicerpt/derivative/pdf/srsmg\%282002\%2901.pdf

Energy Information Administration (US). Emissions of Greenhouse Gases Report [Internet]. Washington D.C.: Department of Energy, Energy Information Administration. 2009 Dec. 3. [cited 2012 Feb. 6]. Available from: http://www.eia.gov/oiaf/1605/ggrpt/carbon.html

Energy Information Administration (US). Oil and Gas Lease Equipment and Operating Costs 1994 through 2009 [Internet]. Washington D.C.: Department of Energy, Energy Information Administration. 2010 Sept. 28. [cited 2011 Sept. 20]. Available from: http://www.eia.gov/pub/oil_gas/natural_gas/data_publications/cost_indices_equipment_p roduction/current/coststudy.html

Energy Information Administration (US). Annual Energy Outlook 2011 [Internet]. Washington D.C.: Department of Energy, Energy Information Administration. 2011a Apr. [cited 2011 Sept. 20]. Available from: http://www.eia.gov/forecasts/archive/aeo11/pdf/0383\%282011\%29.pdf

Energy Information Administration (US). Review of Emerging Resources: U.S. Shale Gas and Shale Oil Plays [Internet]. Washington D.C.: Department of Energy, Energy Information Administration. 2011b July. [cited 2012 Jan. 28]. Available from: $\mathrm{ftp}: / / \mathrm{ftp}$.eia.doe.gov/natgas/usshaleplays.pdf 
Energy Information Administration (US). U.S. Natural Gas Wellhead Price [Internet]. Washington D.C.: Department of Energy, Energy Information Administration. 2012a Jan. 30. [cited 2012 Feb. 4]. Available from:

http://www.eia.gov/dnav/ng/hist/n9190us3M.htm

Energy Information Administration (US). AEO2012 Early Release Overview [Internet]. Washington D.C: Department of Energy, Energy Information Administration. 2012b Jan. 23. [cited 2012 Jan. 28]. Available from:

http://www.eia.gov/forecasts/aeo/er/early_introduction.cfm

Environmental Protection Agency (US). EPA's Study of Hydraulic Fracturing and It's Potential Impact on Drinking Water Resources [Internet]. Washington D.C.: United States Environmental Protection Agency. 2012 Mar. 6. [cited 2012 Mar. 13]. Available from: http://www.epa.gov/hfstudy/

EQT Corporation. EQT Corp, (EQT) Form 10-K, Annual report persuant to section 13 and 15(d), Filed on 02/24/2011, Filed Period 12/31/2010.. Bloomberg Businessweek [Internet]. 2011 Feb. 24 [cited 2011 Oct. 11];120. Available from: http://investing.businessweek.com/research/stocks/financials/secfilings.asp?ticker=EQT: US

Everett J, O’Neil C. Module 10 - Section 6, Depletion Deductions. TaxPoint - An Interactive Taxation Course [Internet]. 2001 [cited 2012 Jan. 20];3. Available from: http://taxpoint.swcollege.com/taxpoint_2001/student/m10/m10-6.html

Fahey J. Low Prices Prompt Chesapeake to Cut Natural Gas Production. USA Today [Internet]. 2012 Jan. 23 [cited 2012 Feb. 10];2. Available from:

http://www.usatoday.com/money/industries/energy/story/2012-01-23/chesapeake-energynatural-gas-drilling/52753478/1

Federal Energy Regulatory Commission (US). Glossary [Internet]. Washington D.C.: Department of Energy, Federal Energy Regulatory Commission. 2010 Jun 28. [cited 2012 Jan 13]. Available from: http://www.ferc.gov/help/glossary.asp\#W

Federation of Tax Administrators. Range of State Corporation Income Tax Rates [Internet]. Washington D.C.: Federation of Tax Administrators; 2011 Feb. [cited 2012 Jan. 14]. Available from: http://www.taxadmin.org/fta/rate/corp_inc.pdf

Flynn P. EIA Expects Highest Natural Gas Supplies Since 1983. Futuresmag [ Internet]. 2012 Feb. 10 [cited 2012 Feb. 12];1. Available from:

http://www.futuresmag.com/News/2012/2/Pages/Natural-gas-ends-March-with-highestsupply-since-

1983.aspx?utm_source=DailyMarketFocus\&utm_medium=eNL\&utm_campaign=FUT_e NL 
Green E. Marcellus Shale Could be a Boon or Bane for Landowners. Pittsburgh PostGazette [Internet]. 2010 Feb. 28 [cited 2011 Nov. 14];4. Available from: http://www.post-gazette.com/pg/10059/1038976-28.stm

Hefley, WE, Seydor, SM, Bencho, MK, Chappel, I, Dizard, M, Hallman, J, Herkt, J, Jiang, PJ, Kerec, M, Lampe, F, Lehner, CL, et al. The economic impact of the value chain of a marcellus shale well. University of Pittsburgh Katz Graduate School of Business [Internet]. 2011 Aug. [cited 2011 Nov. 10];1-92. Available from: http://www.business.pitt.edu/faculty/papers/PittMarcellusShaleEconomics2011.pdf

Holl, N. Natural Gas Prices Hit Trifecta: Increased Supply, Mild Winter \& Exxon. Energy and Capital [Internet]. 2012 Feb. 2. [cited 2012 Feb. 2];1. Available from: http://www.energyandcapital.com/articles/natural-gas-prices-hit-trifecta-increasedsupply-mild-weahter-exxon/2041

Internal Revenue Service (US). Depletion (publication 535). Washington D.C.: Department of the Treasury, Internal Revenue Service. 2010. [cited 2012 Jan. 14]. Available from: http://www.irs.gov/publications/p535/ch09.html

Internal Revenue Service (US). Instructions for form 1120 U.S. corporate income tax return [Internet]. Washington D.C.: Department of the Treasury, Internal Revenue Service. 2012 Jan. 23. [cited 2012 Jan. 25]. Available from: http://www.irs.gov/pub/irspdf/i1120.pdf

Internal Revenue Service (US). Publication 535 - Chapter 7, Costs You Can Deduct or Capitalize [Internet]. Washington D.C.: Department of the Treasury, Internal Revenue Service. 2011. [cited 2012 Jan. 20]. Available from: http://www.irs.gov/publications/p535/ch07.html\#en_US_2010_publink1000208883

Internal Revenue Service (US). Publication 946, How to Depreciate Property; Chapter 4, Figuring Depreciation Under MACRS [Internet]. Washington D.C.: Department of the Treasury, Internal Revenue Service. 2010. [cited 2011 Dec. 15]. Available from: http://www.irs.gov/publications/p946/ch04.html

Jacoby, HD, O'Sullivan, FM, and Paltsev, S. The influence of shale gas on U.S. energy and environmental policy, Economics of Energy and Environmental Policy 2012; $1(1): 37-51$

Krauss C. Commodity Prices Tumble. The New York Times [Internet]. 2008 Oct. 13 [cited 2011 Dec. 8];4. Available from: http://www.nytimes.com/2008/10/14/business/economy/14commodities.html?_r=1\&page wanted=all

Meyer, G. US Approves First Natural Gas Exports. The Financial Times [Internet]. 2011 May 21. [cited 2012 Mar. 10];2. Available from: http://www.ft.com/intl/cms/s/0/bd359e0a-8318-11e0-85a4-00144feabdc0.html 
MIT Energy Initiative. The Future of Natural Gas: An Interdisciplinary MIT Study Interim Report. Cambridge (MA): Massachusetts Institute of Technology; 2010 May 28. 104

Natural Gas Forum for Landowners [Internet]. Lakewood (PA): Natural Gas Lease Offer Tracker; 2011 Oct 28. [cited 2011 Nov 5]. Available from:

http://www.naturalgasforums.com/natgasSubs/naturalGasLeaseOfferTracker.php.

Naturalgas.org [Internet]. Washington D.C.: Natural Gas - from wellhead to burner tip. 2010. [cited 2011 Oct 15]. Available from:

http://www.naturalgas.org/naturalgas/naturalgas.asp

Naturalgas.org [Internet]. Washington D.C.: Well Completion. 2010. [cited 2011 Sept

15]. Available from: http://www.naturalgas.org/naturalgas/well_completion.asp.

Naturalgas.org [Internet]. Washington D.C.: Natural Gas Demand. 2011. [cited 2012 Jan 15]. Available from: http://www.naturalgas.org/business/demand.asp

Oilgasglossary.com. Workover Rig Definition [Internet]. Oilgasglossary.com - Oil \& Gas Field Technical Terms Glossary; 2012. [cited 2012 Feb. 16]. Available from: http://oilgasglossary.com/workover-rig.html

O'Neil, L. Pennsylvania Marcellus Exceeds Natural Gas Output Expectations. thetimestribune.com [Internet]. 2010 Sept. 9. [cited 2011 Dec. 16];2. Available from: http://thetimes-tribune.com/news/marcellus-shale-production-data-exceeds-expectations1.1000300\#axzz1dEPcSXau

Parent, L. Increasing Supply Options and Stagnant Demand Spell Low Gas Prices. World Oil. 2010; 231(2): 65-67

PetroChase. Tax Advantages of Oil and Gas Drilling [Internet]. Scottsdale (AZ):

PetroChase - An Independent Oil and Gas Firm; 2009. [cited 2012 Jan. 20]. Available from: http://www.petrochase.com/tax.html

Range Resources Corporation. Range Resources Corp, (RRC) Form 10-k, Annual report pursuant to section 13 and 15(d), Filed on 03/01/2011, Filed Period 12/31/2010.

Bloomberg Businessweek [Internet]. 2011 Mar. 1 [cited 2011 Oct. 10];69. Available from:

http://investing.businessweek.com/research/stocks/financials/secfilings.asp?ticker=RRC: US

Schaefer K. Natural Gas: Costs Go Down as Learning Curve Goes Up. Resource Investor - News That Trades [Internet]. 2009 June 6 [cited 2011 Aug. 15];2. Available from: http://www.resourceinvestor.com/2009/06/06/natural-gas-costs-go-down-as-learningcurve-goes-u 
Schlumberger [Internet]. 2011. Houston (TX): Schlumberger Limited. Schlumberger Oilfield Glossary. [cited 2012 Feb 16]. Available from:

http://www.glossary.oilfield.slb.com/Display.cfm?Term=workover

Schoen J. Big Oil Says Hands Off Our Tax Breaks. MSNBC.com [Internet]. 2011 May 12 [cited 2012 Jan. 15];4. Available from:

http://www.msnbc.msn.com/id/42996868/ns/business-oil_and_energy/t/big-oil-sayshands-our-tax-breaks/

Smith M. Why Are Natural Gas Producers Expanding Production So Aggressively? Seeking Alpha [Internet]. 2009 Aug. 7 [cited 2011 June 3];5. Available from: http://seekingalpha.com/article/154616-why-are-natural-gas-producers-expandingproduction-so-aggressively

Society of Petroleum Evaluation Engineers [SPEE]. SPEE Recommended Evaluation Practice \#6 - Definition of Decline Curve Parameters Houston (TX): Society of Petroleum Engineers; 2002. 7

The American Petroleum Institute Holds a Conference Call Briefing to Outline the Economics of Shale Gas Production - Final [Conference Call]. The American Petroleum Institute. Fair Disclosure Wire; 2011 July 6 published.

Western Capital Inc. Oil and Gas Tax Benefits [Internet]. Houston (TX): Western Capital Inc.; 2007. [cited 2012 Jan. 25]. Available from:

http://www.oilandgasjointventures.com/tax-benefits.html 